\title{
Phylogenetic relationships of psammosteid heterostracans (Pteraspidiformes), Devonian jawless vertebrates
}

\section{Vadim Glinskiy}

Institute of Earth Sciences, Saint Petersburg State University, Universitetskaya nab., 7-9, Saint Petersburg, 199034, Russian Federation

Address correspondence and requests for materials to Vadim Glinskiy, vadim.glinskiy@gmail.com

\begin{abstract}
Psammosteid heterostracans are a group (suborder Psammosteoidei) of Devonian-age jawless vertebrates, which is included in the order Pteraspidiformes. The whole group of psammosteids is represented by numerous species (more than 40); their phylogenetic relationships are still poorly known and deserve further study. Classical researchers of the psammosteids, such as D. Obruchev, E. Mark-Kurik and L. Halstead Tarlo, had different views on the phylogeny of the group (e.g. origins and evolution of Psammosteus). To check the modern hypotheses of psammosteid origins from various Pteraspidiformes and to clarify psammosteid interrelationships, the most complete phylogeny of this group (38 ingroup taxa + juvenile Drepanapsis) is presented here. Different methods of data analysis were used to explore the psammosteid data set, including equally weighted characters versus implied weighting. According to the results of the phylogenetic analysis, the monophyletic status of the group and their early development from the Pteraspidiformes are supported. The diagnoses and interrelationships of many taxa are clarified. Two new genera are proposed (Vladimirolepis gen. nov. and Elgaia gen. nov.), and two subfamilies are erected (Placosteinae subfam nov. and Psammosteinae Traquair).
\end{abstract}

Keywords: Agnatha, Heterostraci, Pteraspidiformes, psammosteids, phylogeny, classification.

\section{Introdution}

\section{HISTORY OF GENERAL PSAMMOSTEID CLASSIFICATION IN HETEROSTRACI AND PREVIOUS PHYLOGENETIC ANALYSES}

Ramsay H. Traquair (1896, p. 260) first introduced the family Psammosteidae as the name for some Middle and Upper Devonian jawless vertebrates from the Baltic Region and Scotland, grouped in the genus Psammosteus. Traquair also introduced the family Drepanaspidae for Drepanaspis and showed that both families belong to the Heterostraci (Traquair, 1899, pp. 844 , 853). He was the first to point out the similarity of the skeletal plates of Pteraspis and Drepanaspis in their general shape (Traquair, 1899, p. 851). However, he considered that the evolution to pteraspids was accompanied by consolidation of the dermal skeleton from the separate scales of thelodonts to the plates of psammosteids and further, through drepanaspids, to completely consolidated pteraspids (Traquair, 1899, pp. 856857). Thereafter the classification of psammosteids sensu stricto (Drepanaspis through Psammosteus) into two families was widely used (Berg, 1940; Brotzen, 1936; Gross, 1933b; Obruchev, 1941; Traquair, 1900, etc.). However, some authors have used families Drepanaspidae and Psammosteidae disorderly (e.g. Gross, 1937a, b), or synonymously only as the family Drepanaspidae (Stensiö, 1927; White, 1935) or only as the family Psammosteidae (Berg, 1955; Obruchev, 1943b; 
Woodward, 1910). The drepanaspids and psammosteids with some new forms such as Obruchevia (syn. Aspidosteus) were united by several authors in the suborder Psammosteida (Gross, 1935; Kiaer, 1932; Tarlo, 1962), order Psammosteiformes (Berg, 1937 (nomen nudum); Berg, 1940). Later they were assigned to the order Psammosteida (Obruchev, 1964; Obruchev and Mark-Kurik, $1965)$ in the group Heterostraci. For example, the classification of psammosteids used by Leo S. Berg (1940), in which Aspidosteus (syn. Obruchevia) is included in the family Weigeltaspidae (this family would be present in the classification of psammosteids for a long time by iteration), looked like this:

Order Psammosteiformes Berg, 1940

Family Psammosteidae Traquair, 1896

Family Drepanaspidae Traquair, 1899

Family Weigeltaspidae Brotzen, 1933

Aspidosteus Obruchev, 1941 (syn. Obruchevia)

In his early works Dmitry V.Obruchev (1941) segregated psammosteids sensu stricto into the same families in the suborder of psammosteids. The genus Aspidosteus (syn. Obruchevia) was attributed to the Cardipeltidae:

Suborder Psammosteida Kiaer, 1932

Family Psammosteidae Traquair, 1896

Family Drepanaspidae Traquair, 1899

? Family Weigeltaspidae Brotzen, 1933

Family Cardipeltidae Bryant, 1933

Cardipeltis Branson et Mehl, 1931

Aspidosteus Obruchev, 1941 (syn. Obruchevia)

The families Cardipeltidae and Weigeltaspidae were later excluded from psammosteids (Halstead, 1993).

In his later works Berg (1955) substantially broadened the order Psammosteiformes by including the other tesselated heterostracans in it. Psammosteids sensu stricto were assigned to the family Psammosteidae while Aspidosteus (syn. Obruchevia) was included into a separate family Aspidosteidae:

Order Psammosteiformes Berg, 1940

Family Psammosteidae Traquair, 1896

Family Aspidosteidae Berg, 1955

Aspidosteus Obruchev, 1941 (syn. Obruchevia)

Family Cardipeltidae Bryant, 1933

Cardipeltis Branson et Mehl, 1931

Family Weigeltaspidae Brotzen, 1933

Weigeltaspis Brotzen, 1933

? Family Tesseraspididae Berg, 1955

Tesseraspis Wills, 1935

The notion about the affinity of the tesselated heterostracan Tesseraspis and psammosteids sensu stricto was later exploited by Erik H.O. Stensio and Tor Ørvig. Psammosteids (Drepanaspis through Psammosteus) were also united with Tesseraspis in the order Drepanaspida (Stensiö, 1958; Ørvig, 1961). Lambert B. Halstead Tarlo united psammosteids sensu stricto with Tesseraspis and some other tesselated heterostracans in the order Psammosteiformes based on the presence of tesserae in the cephalothorax. He also introduced new families of psammosteids (Tarlo, 1962, 1967; Halstead Tarlo, 1964a, 1965):

Order Psammosteiformes Berg, 1940

Suborder Tesseraspidida Tarlo, 1962

Family Tesseraspididae Berg, 1955

Family Weigeltaspidae Brotzen, 1933

Family Corvaspididae Dineley, 1953

Suborder Psammosteida Kiaer, 1932

Family Drepanaspididae Traquair, 1899

Drepanaspis Schlüter, 1887

Psephaspis Ørvig, 1961

Family Guerichosteidae Halstead Tarlo, 1964

Guerichosteus Halstead Tarlo, 1964

Hariosteus Halstead Tarlo, 1964

Schizosteus Obruchev, 1940

Family Pycnosteidae Tarlo, 1962

Pycnolepis Halstead Tarlo, 1964

Pycnosteus Preobrazhensky, 1911

Ganosteus Rohon, 1901

Tartuosteus Obruchev, 1961

Yoglinia Obruchev, 1943

Family Psammolepididae Tarlo, 1962

Psammolepis Agassiz, 1845

Family Psammosteidae Traquair, 1896

Psammosteus Agassiz, 1845 (in this work, Agassiz, 1844)

Crenosteus Halstead Tarlo, 1964

Rohonosteus Halstead Tarlo, 1964

Karelosteus Obruchev, 1933

Suborder Obrucheviida Halstead Tarlo, 1965

Family Obrucheviidae Halstead Tarlo, 1964

Obruchevia Whitley, 1940 (syn. Aspidosteus)

Traquairosteus Halstead Tarlo, 1964

Obruchev thought that psammosteids evolved from pteraspids and had reacquired tesserae (Obruchev, 1943b, 1945, 1972, p.70). This parsimonous hypothesis was acccepted by other scientists (Gross, 1963, 1967; Westoll, 1967, pp. 93-94). W.Gross (1963) supported Obruchev's hypothesis with his study of a juvenile Drepanaspis, which had a consolidated pteraspid-like exoskeleton and lacked tesserae. Obruchev (1964) presented the following classification of psammosteids:

Order Psammosteida Obruchev, 1964

Family Drepanaspididae Traquair, 1899

Drepanaspis Schlüter, 1888 (err., 1887) 
Family Pycnosteidae Tarlo, 1962

? Psephaspis Ørvig, 1961

Schizosteus Obruchev, 1940

Tartuosteus Obruchev, 1961

Pycnosteus Preobrazhensky, 1911

Ganosteus Rohon, 1901

Family Psammolepididae Tarlo, 1962

Psammolepis Agassiz, 1844 (err., 1845)

Family Psammosteidae Traquair, 1896

Yoglinia Obruchev, 1943

Psammosteus Agassiz, 1844

Karelosteus Obruchev, 1933

Family Aspidosteidae Berg, 1955 (syn. Obrucheviidae Halstead Tarlo, 1964)

Aspidosteus Obruchev, 1941 (syn. Obruchevia)

The main monographs on psammosteids (Halstead Tarlo, 1964a, 1965; Obruchev and Mark-Kurik, 1965) came out almost simultaneously. Halstead Tarlo (Halstead, 1973, 1993) noted that in fact his monographs were published in 1965 and 1966. It is important to note that the monograph by Dmitry V.Obruchev and Elga Yu. Mark-Kurik (1965) was published several months earlier (accepted for publication on 23.12.1965) and has priority over the second monograph by L.B. Halstead Tarlo (accepted for publication on 19.02.1966) for descriptions of the same taxa.

In his later works, Obruchev (Obruchev and MarkKurik, 1965; Obruchev, 1967, 1968) returned to his early simpler version of psammosteid classification: the number of families decreased to three (in the 1965 monograph only representatives of Psammosteidae were discussed in detail), and the genus Yoglinia was synonymized with Psammosteus:

Order Psammosteida Obruchev, 1964

Family Drepanaspididae Traquair, 1899

Family Psammosteidae Traquair, 1896

Schizosteus Obruchev, 1940

Tartuosteus Obruchev, 1961

Pycnosteus Preobrazhensky, 1911

Ganosteus Rohon, 1901

Psammolepis Agassiz, 1845

Psammosteus Agassiz, 1844

Karelosteus Obruchev, 1933

Family Aspidosteidae Berg, 1955

Aspidosteus Obruchev, 1941 (syn. Obruchevia)

Obruchev (1967, Fig. 1) depicted a phylogeny of heterostracans, in which pteraspids represent a sister group of psammosteids. It was suggested that the protaspidids (Glossoidaspis, Europrotaspis) are close to the psammosteids due a reduction of the cornual plates (Obruchev and Mark-Kurik, 1965, p.38; Obruchev, 1967, 1968, 1972).
Halstead Tarlo (Halstead, 1973, p. 325) considered tesseraspidids as a basal group for various heterostracans. According to his new concept, tesseraspids were excluded from the order Psammosteiformes, and the family Weigeltaspididae was assigned to a new suborder, Weigeltaspidida, inside Psammosteiformes. The structure of the other part of the suborder remained the same as in his 1965 work:

Order Psammosteiformes Berg, 1940

Suborder Weigeltaspidida Halstead, 1973

Family Weigeltaspididae Brotzen, 1933

Suborder Psammosteida Kiaer, 1932

Family Drepanaspididae Traquair, 1899

Family Guerichosteidae Halstead Tarlo, 1964

Family Pycnosteidae Tarlo, 1962

Family Psammolepididae Tarlo, 1962

Family Psammosteidae Traquair, 1896

Suborder Obrucheviida Halstead Tarlo, 1965

Family Obrucheviidae Halstead Tarlo, 1964

Vindicating the 'theory of consolidation of the exoskeleton in psammosteiformes', Halstead Tarlo mentioned that tesseraspids (not cyathaspids) were the ancestors of psammosteid heterostracans, and traquairaspids represent the transitional stage between psammosteids and pteraspids (Halstead, 1973, Fig. 12). The main argument was that traquairaspids have tesserae between large plates in their juvenile stages (Halstead, 1973, Fig. $6 \mathrm{k}$ ), which later are included in the main plates.

In the last version of his psammosteid classification, Halstead Tarlo (Halstead, 1993) excluded weigeltaspidids from the order. Thus, the order Psammosteiformes became similar in its composition to the suborder Psammosteida sensu Halstead Tarlo, 1964a, 1965 or the order Psammosteida sensu Obruchev, 1964. The suborders Psammosteida and Obrucheviida were not recognized (Halstead, 1993):

Order Psammosteiformes Berg, 1940

Family Drepanaspididae Traquair, 1899

Family Guerichosteidae Halstead Tarlo, 1964

Family Pycnosteidae Tarlo, 1962

Family Psammolepididae Tarlo, 1962

Family Psammosteidae Traquair, 1896

Family Obrucheviidae Halstead Tarlo, 1964

With the discovery of anchipteraspids (Elliott, 1984), it became clear that pteraspids evolved from cyathaspids. The hypothesis of independent evolution of cyathaspids and pteraspids from tesselated heterostracans was untenable. Psammosteids are grouped with pteraspids according to Obruchev's hypothesis. Alain Blieck in cooperation with David K. Elliott (Blieck, 1984, Fig. 61) made the first (hand-constructed) cladogram of the Pteraspidiformes, 
in which the psammosteid clade (coded Drepanaspis gemuendenensis) is a sister group (order Psammosteiformes) of Pteraspidiformes (consistently positioned at the base of the tree). This author compared Drepanaspis with Cosmaspis. He noted in detail the similar body plan of pteraspids (Protopteraspis) and psammosteids (Blieck, 1984, p. 99). In the subsequent work (Blieck, Elliott, and Gagnier, 1991), data on anchipteraspids were included, and the protopteraspidids were considered as the sister group of the higher pteraspids and psammosteids on the basis of the primitive location of pineal canal. In the proposed phylogenetic scheme by P. Janvier (1996, Fig. 4.9), psammosteids were placed as the sister group to protaspidids (as a development of Obruchev's traditional hypothesis) and combined with them in the new superfamily Protaspidoidea.

Vincent N. Pernègre (2002) compiled a new character-taxon matrix and produced a cladistic analysis that included Drepanaspis gemuendenensis. In the most parsimonious tree, recovered by him, this psammosteid was placed as a sister taxon to Doryaspis nathorsi in the order Pteraspidiformes. The close relationship between Doryaspis and psammosteids was criticized (Elliott and Mark-Kurik, 2005, p. 107) due to differences in squamation and position, pattern and number of plates in their cephalothoraxes. Pernègre and Elliott (2008) published a strict consensus tree including Drepanaspis gemuendenensis, based on a substantially improved and expanded matrix. According to their cladogram, psammosteids are also included in the order Pteraspidiformes and placed between the basal family Anchipteraspididae and the family 'Protopteraspididae' (Pernègre and Elliott, 2008, Fig. 5). Emma Randle and Robert Sansom (2016, 2017), using discrete, continuous and discretized continuous characters, encoded 47 taxa of pteraspidiforms including two well known species of psammosteids - Drepanaspis gemuendenensis and Psammosteus megalopteryx. In all resulting trees using different characters / coding methods and methods of data analysis (equal character weights or implied character weighting), psammosteids fall into the clade Pteraspidiformes (Randle and Sansom, 2016, Figs. 4-6). In most cases (5 of 6 presented trees), the position of psammosteids in a clade with Doryaspis and Woodfjordaspis is maintained (development of Pernègre's hypothesis). It was proposed that psammosteids should be included in the new superfamily Doryaspidae (most correct - Doryaspidoidea).

Still, the position and rank of psammosteids in the order Pteraspidiformes is ambiguous. Currently psammosteids are often regarded as the family Psammosteidae (Janvier 1996; Pernègre and Elliott, 2008; Randle and Sansom, 2016). Also they are assigned to the suborder Psammosteida in the order Pteraspidiformes (Elliott, Mark-Kurik, and Daeschler, 2004; Glinskiy and Mark-Kurik, 2016; Glinskiy and Nilov, 2017).
Presented here is a new most complete cladistic analysis, which has been carried out in order to determine the phylogenetic relationships of psammosteid heterostracans. All reasonably well known species of psammosteids have been included. These phylogenetic relationships of psammosteids were presented for the first time at the Early Lower Vertebrates Symposium in Poland (Glinskiy, 2017; abstract + poster). The results of a preliminary analysis (Anchipteraspididae were not included ) confirm the data of A. Blieck and D. K. Elliott (1984), that psammosteids are a monophyletic group (order Psammosteiformes), and that pteraspids (Pteraspidiformes) are their sister group.

\section{DEVELOPMENT OF VIEWS ON PHYLOGENETIC INTER- RELATIONSHIPS WITHIN PSAMMOSTEIDS}

Walter Gross (1930, p.127, 1933a, p.7) was the first to point out the homology of the branchial plates of the Middle Devonian psammosteids with those of Drepanaspis. He also made suggestions about the evolution of these exoskeletal elements, which involved their contraction and widening. Gross (1933a) divided psammosteids according to the length of their branchial plates into Psammolepis and Psammosteus. He noted similarities of the branchial plates of Schizosteus striatus (syn. Psammolepis striata sensu Gross) with those of Drepanaspis. Obruchev (1940) established the genus Schizosteus, which he treated as a transitional form between Drepanaspis and other psammosteids. He pointed out (Obruchev, 1940, Fig. 4, 1943b, etc.) variability in the depth of the ventral plates' posterior notch, showing that this notch is similar in Drepanaspis and Schizosteus. Obruchev (1943a) described a 'pteraspid' Yoglinia; later it was assigned to psammosteids (Mark, 1955), attributed to the family Psammosteidae (Obruchev, 1964) and synonymized with Psammosteus (Obruchev and Mark-Kurik, 1965). Obruchev (1943c) produced in his thesis the first phylogeny of the psammosteid genera Pycnosteus, Ganosteus and subsequently Psammolepis and Aspidosteus (syn. Obruchevia) and showed that they consistently branched out from the stem line from Drepanaspis to Psammosteus (Fig. 1A). According to this scheme, psammosteids are descendants of pteraspids. This phylogeny quite accurately anticipates the phylogenetic relationships of the main psammosteid genera (with the exception of Obruchevia) obtained in the present work (Fig. 3). Mark-Kurik (Mark, 1955) described many new psammosteids from the Baltic region in her dissertation and presented a detailed discussion of their evolutionary relationships, including a phylogenetic scheme (Fig. 1C). She followed the view of Obruchev (1943c) about independent evolution of two groups (Pycnosteus + Ganosteus and Psammolepis) from Schizosteus (the data on the concentric lines of growth on branchial and ventral plates at juvelile stages of the development was taken into account). A suggestion was proposed that Schizosteus striatus is the 

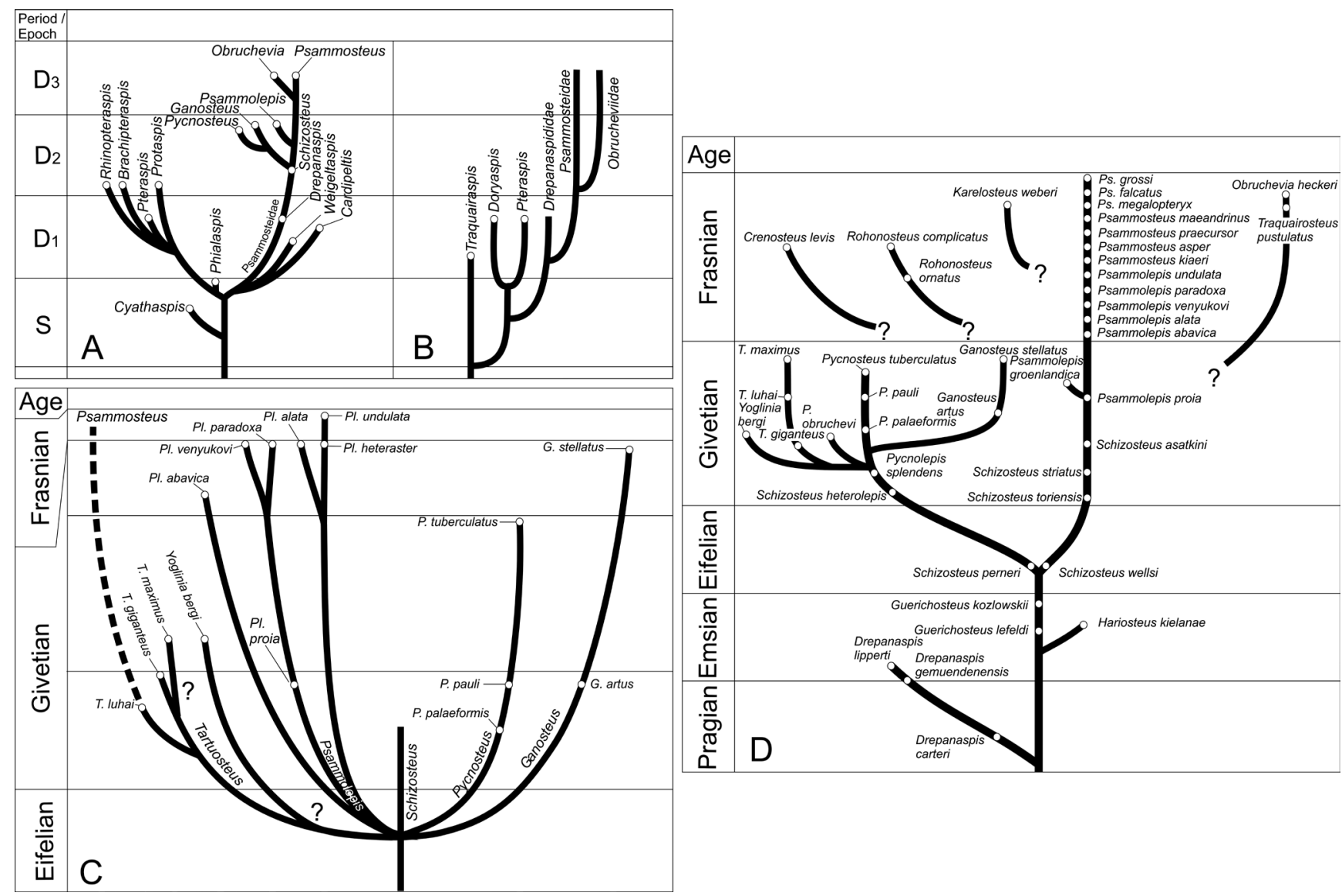

Fig. 1. Previous phylogenies of the psammosteid heterostracans. A, First phylogeny of psammosteid genera, grouped in the family Psammosteidae from D. Obruchev's thesis (1943c). B, Phylogeny of psammosteid families (Drepanaspidae, Psammosteidae, Obrucheviidae) by Obruchev, 1967 (in both cases the new names of taxa are used). C, Phylogeny of psammosteid species from E. Mark thesis (1955) excluding species - junior synonyms (Obruchev and Mark-Kurik, 1965). D, Tentative phylogeny of psammosteid species by Halstead Tarlo (1964a) with corrections of Tarlo (1967) and Halstead (1993) and excluding some species, junior synonyms and the Famennian non-psammosteid vertebrate 'Psammolepis' granulata (Blieck, 1991).

ancestor of Psammolepis proia (syn. Vladimirolepis proia comb. nov.), and 'Psammolepis' heteraster, 'Psammolepis' alata and 'Psammolepis' undulata (syn. Placosteus) represent a separate phylogenetic line within Psammolepis. Mark-Kurik reckoned that Tartuosteus luhai (syn. Elgaia luhai, comb. nov.) is the ancestor of the Psammosteus line, and Yoglinia (syn. Psammosteus) is close to Psammosteus (ibid., p.17), but she somehow placed Yoglinia between Tartuosteus and Psammolepis in her scheme. Halstead Tarlo (Tarlo, 1957, 1962, etc.) described psammosteids (Guerichosteidae) from the Emsian of Poland and negated Obruchev's view about the evolution of psammosteids from Drepanaspis (Tarlo, 1957, p.228). He further suggested that psammosteids evolved into two independent lineages - marine (represented by Drepanaspis), which didn't produce descendants, and freshwater, represented by guerichosteids and their descendants that produced other psammosteids (Tarlo, 1957, 1962, Figs. 13, 15; Halstead Tarlo, 1964a, Figs. 30-32) (Fig. 1D). The views of Halstead Tarlo on psammosteid evolution are also based on the variation of the shape of median plates, development of their tesserae covering, and changes in propor- tions of branchial plates (Halstead Tarlo, 1964a, Figs. 30, 31; Halstead, 1973). The resultant phylogenetic scheme (Halstead Tarlo, 1964a, Fig. 32) differs from the previous two only slightly in details - in terms of the evolution of Yoglinia (syn. Psammosteus) and Tartuosteus luhai (syn. Elgaia, gen. nov.) (Fig. 1D). The genera Guerichosteus, Schizosteus, and Psammolepis should be considered paraphyletic, according to his scheme. The species of the genus Schizosteus (member of Guerichosteus) gave the different evolutionary lineages - pycnosteids (some Schizosteus, Pycnosteus, Ganosteus, Tartuosteus, Yoglinia) and psammolepidids-psammosteids (some Schizosteus, Psammolepis, Rohonosteus, Traquairosteus, Obruchevia, Psammosteus, Karelosteus). The genus Psammosteus, according to Halstead Tarlo, evolved from Psammolepis (Halstead Tarlo, 1964a, p. 103), and Karelosteus is considered a sidebranch of Psammosteus. Traquairosteus with Obruchevia, Rohonosteus and Crenosteus are considered prospective descendants of the basal and more derived psammolepidids, respectively. His views on the evolution within Psammosteus in this work are systemless. Halstead Tarlo (1964a, 1965) considered the similar characters of the branchials 
of Yoglinia and Psammosteus to be a result of parallel evolution. He followed Obruchev (1961) in the erroneous attribution of the tesselated dorsal plate of 'Psammolepis' proia (Vladimirolepis gen. nov.) to Tartuosteus giganteus.

Obruchev and Mark-Kurik (1965, p.66, 67, 1968) used quantitative data (length/width ratio) for the first time to characterize the main plates of the psammosteid exoskeleton. The authors in general shared Halstead Tarlo's viewpoint on the evolution of the group. However, they negated his (1964) hypothesis about the probable evolution of Psammosteus from late representatives of Psammolepis ('Pl'. undulata). They noted that the earliest Psammosteus bergi appeared substantially earlier than 'Pl'. undulata (though the similarity in general body shape (which is elongated) of Ps. bergi and Pl. undulata is also pointed out). The authors noted well-traced relationships between psammosteid species (Tartuosteus giganteus Tartuosteus maximus; relationships inside the genus $P y c$ nosteus, Ganosteus artus - Ganosteus stellatus, 'Psammolepis' alata - 'Psammolepis' undulata [syn. Placosteus], Psammosteus praecursor - Psammosteus maeandrinus). Three evolutionary lineages were also distinguished (Obruchev and Mark-Kurik, 1968, p. 282) based on the study of juvenile plates and concentric growth lines. They are the following: slender-bodied psammosteids (close to Drepanaspis, including Schizosteus striatus and almost all Psammolepis), wide-bodied psammosteids (including Schizosteus splendens [syn. Pycnolepis], Tartuosteus, Pycnosteus, Ganosteus and several species of Schizosteus and Psammolepis), and psammosteids with rhombic dorsal plate and broad branchials (Psammosteus bergi). Tartuosteus? luhai (syn. Elgaia luhai comb. nov.) and Psammosteus (Yoglinia) bergi were attributed to different phylogenetic lines (Obruchev and Mark-Kurik, 1968, p.282), despite the presence of shared characters in the structure of the branchial and dorsal plates.

Robert H.Denison (1968, pp.279, 281) attributed Psephaspis to pteraspids (this genus had previously been attributed by T. Ørvig to psammosteids) based on the absence of tesserae (they were mistakenly identified due to the fractured state of the remains). Denison also proposed that 'Psephaspis' bystrowi (Drepanaspis sp. according to Bystrow, 1959), described based on a tessera, should be named? Drepanaspis sp. Obruchev in his works (Obruchev, 1967, 1968) considered phylogenetic relationships within evolutionary lineages of psammosteids (Fig. 1B). According to him, drepanaspids gave rise to psammosteids, and obrucheviids evolved from psammosteids as a 'late aberrant offshoot' (Obruchev, 1967, p.42). In that work Obruchev also showed recapitulation of ancestral characters in the Middle Devonian psammosteids. In his next article Obruchev specified that obrucheviids were classified as 'aberrant descendants of psammosteids, evolved from their earliest representatives' (Obruchev, 1968, p.26). Halstead Tarlo (Halstead, 1973, p.291) dis- covered pedomorphism in branchial plates of psammosteids Ganosteus and Psammosteus (Yoglinia). Scientists traced (Halstead Tarlo, 1964, p. 105-107; Halstead, 1973, p.291) two evolutionary lineages in Psammosteus based on the shapes of branchial plates. Larisa I. Novitskaya (2004) used the classification by Obruchev (1964) in her revision of psammosteids. The genera Yoglinia and Crenosteus were synonymized with Psammosteus, Pycnolepis with Schizosteus and Rohonosteus with Tartuosteus. It was proposed that the most correct name for the suborder Psammosteida is Psammosteoidei (Novitskaya, 2004, p.171). New data on Obruchevia and Perscheia (Elliott, Mark-Kurik, and Daeschler, 2004) showed that obrucheviids are more likely to be connected to a group including Pycnolepis, Pycnosteus and Tartuosteus. Sergey V. Moloshnikov (2009) introduced the genus Oredezhosteus which was later rejected (Glinskiy and Mark-Kurik, 2016). New morpho-histological characters of the plates of some representatives of Psammosteus made it possible to compare the histology of these taxa with Traquairosteus pustulatus and divide the genus Psammosteus on the two evolutionary lines (genera in the future) (Glinskiy and Nilov, 2017).

\section{Phylogenetic analysis}

\section{CHARACTERS, CODING METHODS AND DATA ANALYSIS}

The new matrix is composed of 49 taxa and 120 discrete characters (49 characters are new) (see Appendix 1). The list of encoded taxa, specimen information and museum numbers are organized in a table (on-line only Supplements 1 and 2). 38 species from 16 genera (constituting the ingroup taxa) are coded as belonging to the morphologically best-known psammosteid heterostracans. To understand the relationship between pteraspids and psammosteids, juvenile Drepanapsis gemuendenensis was encoded as a separate taxon, because juvenile psammosteids show recapitulations (Gross, 1963; Obruchev, 1967). Thus, all the well known psammosteid species (except Traquairosteus pustulatus and species of Rohonosteus) are included here. Most included psammosteid taxa are known from numerous various elements of the exoskeleton; the exception is a group of taxa from the family Psammosteidae, known primarily from the branchial plates and tesserae: Psammosteus levis, P.tenuis, Karelosteus weberi, and the group of species 'Psammosteus' ramosus - 'P.' ' falcatus. For testing various hypotheses of derivation of the psammosteids (Janvier, 1996; Pernègre, 2002; Pernègre and Elliott, 2008; Randle and Sansom 2016), eight taxa of the order Pteraspidiformes, which may form the sister group to psammosteids, were encoded: Anchipteraspis crenulata, Doryaspis nathorsti, Errivaspis waynensis, Gigantaspis laticephala, Protaspis bucheri, Protopteraspis vogti, Woodfjordaspis felixi, and Xylaspis prima. Two cyathaspidiform taxa, Anglaspis 
maccoulloughi (outgroup taxon in TNT) and Nahanniaspis mackenziei were chosen as outgroups, because they are very useful in polarizing character states within the analysis (Pernègre and Elliott, 2008; Randle and Sansom, 2016).

Characters used in the phylogenetic analysis were obtained from direct study, published descriptions, or were taken unchanged or adapted from previous phylogenies (Ilyes and Elliott 1994; Pernègre, 2002; Pernègre and Goujet, 2007; Pernègre and Elliott, 2008; Randle and Sansom, 2016) (Appendix 1). Figure 2 provides a visual explanation of some ratios of plates, which were used in character codings. For each psammosteid taxon, text and graphic data on the type specimens were used (Elliott, Mark-Kurik, and Daeschler, 2004; Elliott and Mark-Kurik, 2005; Halstead Tarlo, 1964a, 1965; Lyarskaya, 1971; Mark-Kurik, 1968, 1993, 1999; Novitskaya, 1965, 2004; Obruchev, 1940; Obruchev and Mark-Kurik, 1965; Růžička, 1929; Tarlo, 1961). The most recent data on the general morphology, ornamentation and histology of psammosteids were also encoded (Glinskiy, 2014; Glinskiy and Mark-Kurik, 2016; Glinskiy and Nilov, 2017; Glinskiy and Pinakhina, 2018; Keating, Marquart, and Donoghue, 2015; Moloshnikov, 2001). All characters are discrete (binary or multistate), mostly unordered, but 21 multistate characters are ordered as specified by the relationship of character states within the transformation series $(1,8,16,21,30,31,38,54$, $57,64,71,79,81,83,86,87,88,89,99,108,117)$. There are three $(9,61,66)$ uninformative characters $(2.5 \%)$. Characters $29,65,68,81,86,87,91$ were used for determining the geometric ratio for some main plates of the psammosteid cephalothorax; their changes in proportions are important for understanding the evolutionary trends in the group (Halstead, 1973, p.290; Obruchev and Mark-Kurik, 1965, pp. 41-48) (Fig. 2). Continuous or quantitative characters were not used here, due to the fact that psammosteid specimens have a high variability of measurements of the main plates, which are placed in the fields of tesserae (Randle and Sansom, 2016, p. 7). Furthermore, the lateral plates of psammosteids change in form due to life-time abrasion, and specimens discovered with associated cephalothorax also are very rare.

The character-taxon matrix was coded in NDE 0.5.0. by Roderic D. M. Page, 2001, and exported in TNT format implemented through the program Mesquite 3.2. Parsimony tree searches were conducted in TNT 1.5 (Goloboff, Farris, and Nixon, 2008) with space for holding 10000 trees. Two methods of data analysis were carried out- with equally weighted characters and with implied weighting (Goloboff, 2014). In both analyses the heuristic search mode (Traditional search) was used with the 'branch swapping' option (multiple Tree Bisection Reconnection, TBR) with 1000 replications and trees from RAM successively. In addition, the Nelsen strict consensus tree was calculated. Bremer tree support and standard Bootstrap (with traditional search, 5000 rep.) were implemented.

\section{PHYLOGENETIC RESULTS}

The first equal weight analysis produced 36 most-parsimonious trees (MPTs; tree length 373 steps, $\mathrm{CI}=0.611$, $\mathrm{RI}=0.851$, and $\mathrm{RC}=0.520$ ), giving a well-resolved strict consensus tree (Fig. 3A). Psammosteids are nested in the Pteraspidiformes and represented as a monophyletic group suborder Psammosteoidei (=Psammosteida Kiaer, 1932 emend. Tarlo, 1962). Anchipteraspis crenulata is placed as the sister taxon of the other Pteraspidiformes. Protopteraspis vogti fall in the one clade with the derived pteraspids and psammosteids. In Pernegre and Elliott's (2008) phylogeny, Doryaspis was within the 'Protopteraspididae', but here Doryaspis and Woodfordaspis fall within the same clade of Pteraspidoidei (family Doryaspididae N. Heintz in Tarlo 1962), and Xylaspis is included in the Protaspididae. Psammosteids contain six families: Drepanaspididae, Guerichosteidae, Obrucheviidae, Pycnosteidae, Psammolepididae and Psammosteidae. Psammolepis, Tartuosteus, and Schizosteus sensu Obruchev and Mark-Kurik (1965) and Halstead Tarlo (1965) are not united in a monophyletic group and need a revision. The clade with Psammolepis sensu stricto (Psammolepis abavaca, P. toriensis, P.paradoxa, P. venyukovi) is sister to a large clade that also contains the species 'Psammolepis' proia, ' $P$ '. alata, ' $P$ '. undulata, and 'Tartuosteus'? luhai (taxa requiring new generic names). This group of species forms a basal assemblage leading to a clade containing the species of Psammosteus and Karelosteus weberi. A large number of Psammolepis and Psammosteus species are in a polytomy within the consensus tree. Monophyly of Guerichosteus and Schizosteus (requires more material of S.asatkini, which is known only from a juvenile specimen) is not considered. Karelosteus weberi along with 'Psammosteus' livonicus - 'Psammosteus' asper and 'Psammosteus' ramosus - 'Psammosteus' falcatus form the most derived clade of psammosteids. 'Psammosteus' tenuis is the sister taxon for this clade.

To increase resolution, avoiding polytomies in some clades (e.g. in Psammosteus), and to recover any phylogenetic signal, a second implied weighting analysis was conducted (Fig. 3B). Application of implied weighting resulted in 3 MPTs with a score of weighting $(k=4)$ (MPTs length 23.55, $\mathrm{CI}=0.610, \mathrm{RI}=0.850$ and $\mathrm{RC}=$ 0.519 . Relationships in the groups of taxa are somewhat better resolved in the current strict concensus tree than in the previous analysis. Protopteraspis vogti is shown here as the sister taxon to the clade, consisting of psammosteids and derived pteraspids. These results of the implied weighting data analysis support the cladistic 


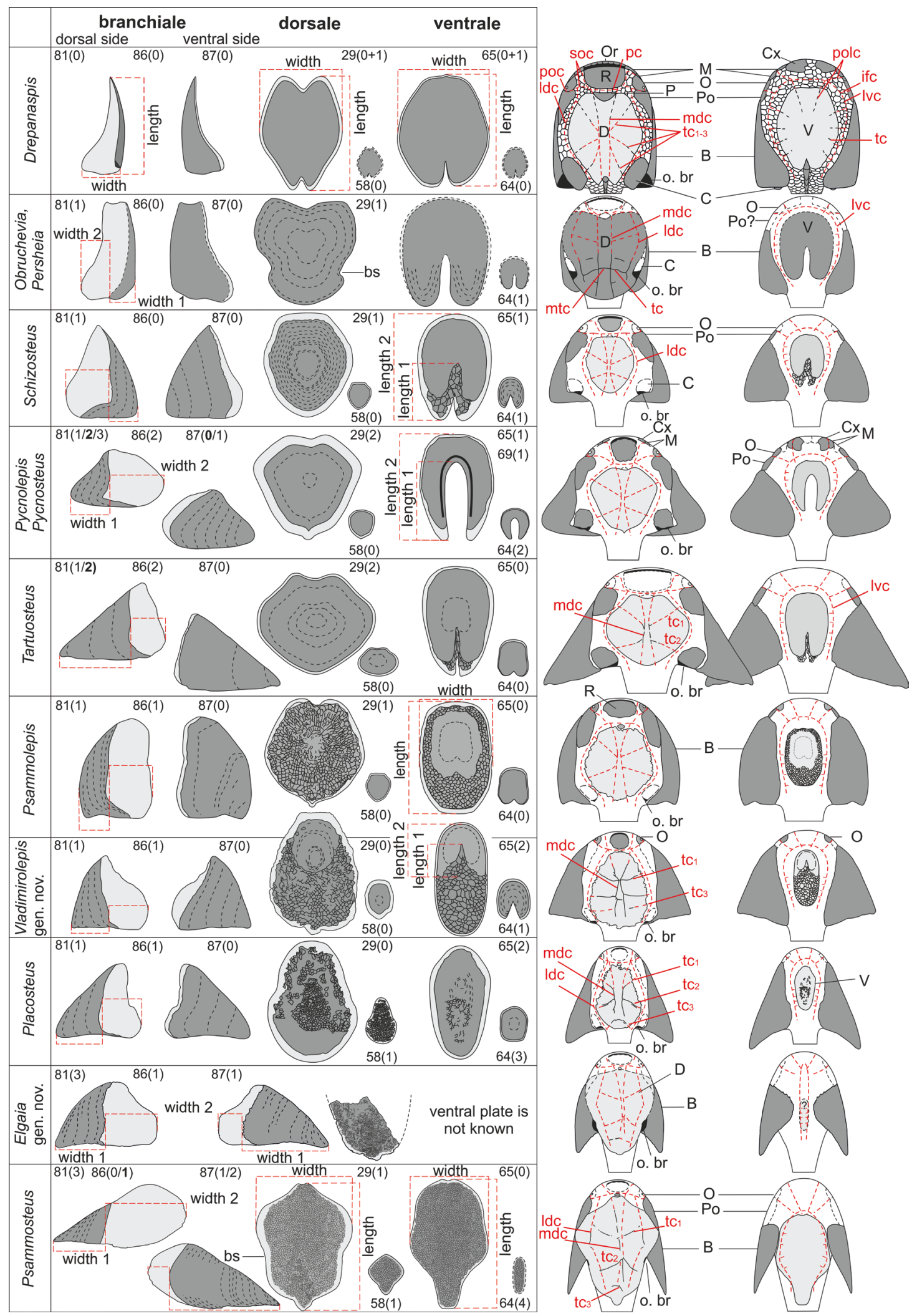

Fig. 2. Reconstructions of the cephalothorax of the major psammosteid genera with measurements of main plates. Reconstructions were made on the basis of the original material given in the list of taxa (On-line only Supplement 1). Numbers signify the selected characters, the following numbers in brackets represent character states. The slashes indicate variation of the character states within the given genus; character state, which is shown in the picture, is highlighted in bold. The variability of the branchial plates' shape in dorsal and ventral view is associated with their dorsally convex shape in the transverse-longitudinal direction. For median plates of some taxa, the juvenile states of the plates are shown. The red dotted lines indicate measurements of ratio as well as proposed canals of the lateral line system; the black dotted lines indicate concentric lines of growth, reflecting the morphology of the plates in ontogenesis. Abbreviations: B, branchial plate; bs, branchial sinus; C, cornual plate; D, dorsal plate; ifc, infraorbital canal; Idc, lateral dorsal canal; Ivc, lateral ventral canal; CX, complex plate; M, marginal plate; mdc, median dorsal canal; mtc, median transverse commissure; O, orbital plate; o.br, branchial openings; Or, oral plate; P, pineal plate; Po, postorbital plate; poc, postorbital canal; polc, postoral canal; pc, pineal canal; R, rostral plate; tc, transverse commissure; soc, supraorbital canal; $V$, ventral plate. 


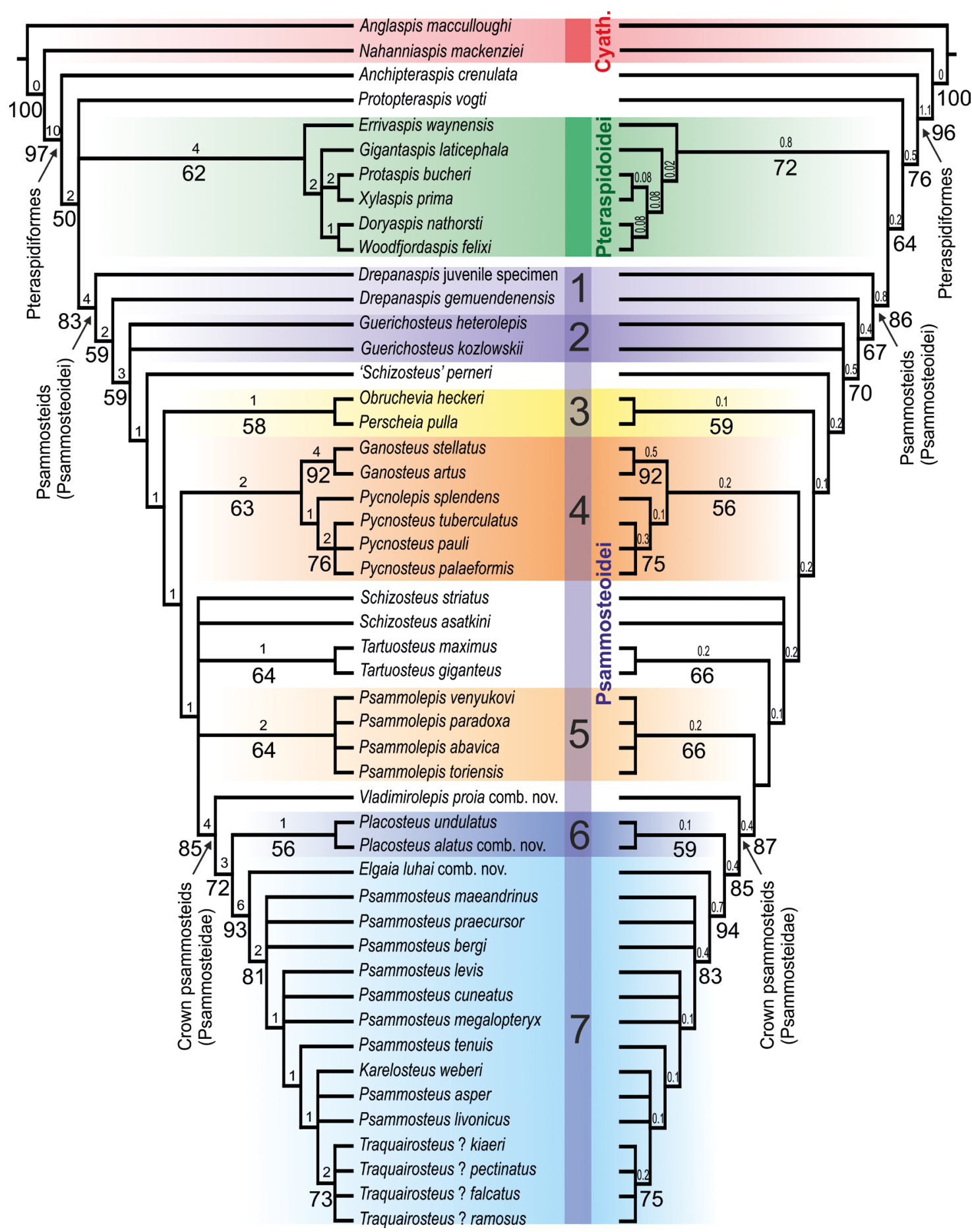

Fig. 3. Results of the phylogenetic analysis of the psammosteid heterostracans. A, strict consensus of 36 most parsimonious trees with equal character weights, MPTs length 373 steps, $\mathrm{Cl}=0.611, \mathrm{RI}=0.851$, and $\mathrm{RC}=0.520$. Pteraspid heterostracans (Pteraspidoidei) are recovered in a clade sister to psammosteids. B, strict consensus of three most parsimonious trees with implied character weighting $(k=4), \mathrm{MPTs}$ length $23.55, \mathrm{Cl}=0.610$, $\mathrm{RI}=0.850$ and $\mathrm{RC}=0.519$, finds high resolution among basal Pteraspidiformes. Bremer and Bootstrap (absolute frequency, more than 50) support values are placed above and below branches respectively. Families of psammosteids: 1, Drepanaspididae; 2, Guerichosteidae; 3, Obrucheviidae; 4, Pycnosteidae; 5, Psammolepididae; 6 and 7, Psammosteidae, where 6, subfamiliy Placosteinae subfam. nov. and 7, subfamily Psammosteinae.

hypothesis by A. Blieck, D. Elliott and P. Gagnier (1991, Fig. 6B). The varied concavity value ( $k$ from 4 to 20 ) was implemented in the implied weighting analysis (length, topology, CI and RI indexes of MPT's and resulted strict consensus trees did not change). Shown here (Fig. 3B) is the result with concavity value $k=4$. The positions of the psammosteid taxa are consistent with their positions in the equally weighted analysis. The results of the implied weighting data analysis with $k$ from 1 to 3 represent some topological incongruence between trees from all previous analyses. According to these results, Doryaspis nathorst $i$ is the most basal representative of Pteras- 
pidoidei clade (family Doryaspididae is not supported). This result appears only with three concavity values and thus requires additional testing. Tree support (standard Bootstrap with traditional search, 5000 rep.) shows high values of absolute frequencies for most clades of psammosteids (Fig. 3). Following the results of the phylogenetic analyses, previous classifications of psammosteids (Halstead, 1993; Novitskaya, 2004) are revised below.

\section{Systematic palaeontology}

Subclass Heterostraci Lankester, 1868

Order Pteraspidiformes Berg, 1940

Suborder Psammosteoidei (sensu Psammosteida Kiaer, 1932 emend. Tarlo, 1962)

Diagnosis (revised). Prerostral plates present (10:1; numbers represent characters and its states of the analysed matrix); anterior margin of rostral plate convex, rounded anteriorly to a point (4:1); postorbital plates present (21:3); median plates surrounded by fields of tesserae (27:1); lateral canals in fields of tesserae (49:2, 76:2); dorsal plate generally rhomboid with anterior and posterior notches (30:1), their lateral margins strongly convex or angular, may also form anterolateral and posterolateral margins (33:2); ventral plate, posterior margin with V-shaped and narrow posterior notch (67:3); branchial plate with anterolateral ledge (78:1) and unequal width of dorsal and ventral lamellae (79:2); medial margin of branchial plates with concave anterior part and slightly convex posterior part (83:1); ornamentation represented by rows of ridges and tubercles (109:2); trabecular aspidin layer (L2) in exoskeleton (120:1).

Taxa included. Familes Drepanaspididae Traquair, 1899; Guerichosteidae Tarlo, 1964; Obrucheviidae Halstead Tarlo, 1964; Pycnosteidae Tarlo, 1962; Psammolepididae Tarlo, 1962; Psammosteidae Traquair, 1896.

Remarks. The clade of psammosteids is well supported, however, some apomorphies change whithin the ingroup. The following apomorphies of the group are identified in both analyses: 10:1, 21:3, 27:1, 30:1, 49:2, $67: 3,76: 2,79: 2,83: 1$. Some features characterize only the basal taxa of the ingroup, e.g. family Drepanaspididae (i.e. 30:1, 83:1). Most canals of the lateral line system (soc, pc, ldc, lvc) of the basal psammosteid Drepanaspis are located in fields of tesserae (Obruchev, 1943b, p. 272; Blieck, Elliott, and Gagnier, 1991, etc.). Some presumed 'apomorphies' of the ingroup were established after analysis (88:1, 89:1, 90:3, 94:2, 95:2, 96:4), but are not included in the diagnosis, since these characters are known in other representatives of Pteraspidiformes (not included in current analyses). For example, reduction or full absence of the cornual plates (90:3), presence of branchial openings on the distal tip of branchial plates $(88: 1,89: 1)$ is not an unique apomorphy of psammoste- ids and occurs also in protaspids. All known psammosteids lack the lamellar aspidin (L3) on the scales (e.g. Elliott, Mark-Kurik, 2005, p. 107), but this character is insufficiently studied on other pteraspids and cannot be used yet.

\section{Family Drepanaspididae Traquair, 1899}

Diagnosis (revised). Prerostral plates present (10:1); anterior margin of rostral plate convex, rounded anteriorly to a point (4:1); rostro-orbital contact absent due tesserae (6:1); postorbital plates present (21:3); median plates surrounded by fields of tesserae (27:1); lateral canals in fields of tesserae (49:2, 76:0); dorsal plate generally rhomboid with anterior and posterior notches (for basal representatives) (30:1), their lateral margins angular, may also form anterolateral and posterolateral margins (33:2); ventral plate, posterior margin with $\mathrm{V}$-shaped and narrow posterior notch (67:3); branchial plate with anterolateral ledge (78:1) and unequal width of dorsal and ventral lamellae (79:2); medial margin of branchial plates with concave anterior part and slightly convex posterior part (83:1).

Taxa included. Drepanaspis gemuendenensis Schlüter, 1887 (included in analysis).

Remarks. The most basal node of the ingroup (Fig. 2). The following apomorphies characterise this basal taxon of the ingroup: 6:1, 10:1, 21:3, 27:1, 30:1, 33:2, 49:2, 67:3, 76:2, 79:2, 83:1. All Drepanaspis gemuendenensis specimens (including juvenile specimens) have fields in the cephalothorax interpreted as fields of tesserae. Following the supposition of Gross (1963, p. 149), I assume that in the case of the most juvenile Drepanaspis, the smallest tesserae (more likely discrete single and complex elements) must be present in the fields of tesserae. So they probably grew more slowly than the plates, not constraining the growth of the latter (unfortunately, the juvenile exemplar of Drepanaspis was lost during WWII). The juvenile Drepanaspis differs from the adult specimens by the more consolidated cephalothorax, which has the following contacts: planar rostro-pineal (8:1), rostro-orbital (6:0), dorso-postorbital, dorso-cornual contacts; triangular pineal plate (14:0). It is possible that the juvenile specimen shows some of the characters of more distant ancestors (recapitulations) (Obruchev, 1967), which would be lost in adults of the same species. Anyway, the juvenile specimen of Drepanaspis falls well in the psammosteid clade as the basal member.

\section{Family Guerichosteidae Halstead Tarlo, 1964}

Diagnosis (revised). Pineal opening (macula) covered by many tubercles on pineal plate (18:2); branchial plates narrow and long with fairly wide, free, laterally projecting margin (anterolateral ledge) (79:3); branchial opening situated at posterior margin (medial from) 
(88:2); ornamentation consisting of large and very large tubercles (more than $1 \mathrm{~mm})(111: 3)$ organized in rows (with the rare ridgelets) (109:3).

Taxa included. Guerichosteus kozlowskii Halstead Tarlo, 1964, G. heterolepis (Preobrazhensky, 1911).

Remarks. These near-basal members of the ingroup are characterized by four synapomorphies (18:2, 79:3, $88: 2,109: 3)$. 'Hariosteus' is known from fragmentary material, which makes revision difficult (presence of the dorsal lamella of the branchial plate is not confirmed), but the characters of the ornamentation indicate that this genus probably is a junior synonym of Guerichosteus. Guerichosteus heterolepis (Preobrazhensky, 1911) is included in the genus Guerichosteus on the basis of the similar morphology of the branchial plates and ornamentation pattern (Glinskiy and Pinakhina, 2018). The genus Schizosteus, previously included in this family (Halstead Tarlo, 1964a), is excluded here given its synapomorphies with higher psammosteids. Despite their similarity, the two species of Guerichosteus do not form a clade, which can be explained by the fragmentary nature of the available material.

\section{Family Obrucheviidae Halstead Tarlo, 1964}

Diagnosis (revised). Lateral margins of dorsal plate convexo-concave with branchial sinus (flexure for branchial opening) and with posterolateral process (33:5, $34: 1)$, posterior and lateral margins with arc-shaped contact (36:2); pleromin fully covering main plates as superficial layer (117:2).

Taxa included. Obruchevia heckeri (Obruchev, 1936); Perscheia pulla Elliott, Mark-Kurik et Daeschler, 2004.

Remarks. This group is characterized by two apomorphies $(33: 5,117: 2)$. Obrucheviids have plates with a sculptured surface of pits, radial grooves or mounds, the outer layers being infilled by pleromic dentine. Obruchev (1941) believed that the plates were located in soft tissues, but later decided that the surface of the plates was not covered with epidermis (Obruchev, 1968). The presence of lateral line canals on the dorsal plate in Perscheia shows that the dorsal surface of obrucheviids was mostly covered by soft tissue in life (Elliott, Mark-Kurik, and Daeschler, 2004, p. 32). The narrow and long branchial plates of Obruchevia (Obruchev, 1968, p. 26) indicate its origin from the early psammosteids, in which the plates had not yet been shortened. I assume that the dorsal exoskeleton in the obrucheviids was strongly consolidated, and the fields of tesserae did not develop or were extremely narrow. The following characters support this conclusion: the presence of lateral canals of the lateral line on the dorsal plate in Perscheia, and the presence of the paired branchial sinus (sensu Obruchev, 1941) on the dorsal plate. Obruchevia was compared with Cardipeltis, but the similarity of dorsal plates was suggested to be caused by convergence (Obruchev, 1941, 1968).
Traquairosteus pustulatus (Traquair, 1897) is known only from an elongated dorsal (probably ventral) plate (Tarlo, 1961, Fig. 6) that is typical for Psammosteidae. Traquairosteus pustulatus isn't included in the current analysis. Moreover, herein Traquairosteus is the proposed generic name of the group of species 'Psammosteus' ramosus - 'Psammosteus' falcatus because all these psammosteids have tubercles on aspidin mounds. The widely spaced tubercles on the main plates of Traquairosteus should be interpreted as the primordial tubercles of the rooted progressive micromeric elements (tesserae) as on the dorsal plate of ' $P$ '. falcatus (Obruchev and Mark-Kurik, 1965, p.66, pl. 88, Fig. 2).

\section{Family Pycnosteidae Tarlo, 1962}

Diagnosis (revised). Ventral plate with large Ushaped posterior notch $(64: 2,67: 4)$ with protruding edges (69:1) and anterior position of plate primordium (70:2); branchial plates wide eurybasal with lengthwidth ratio more than 0.6 (81:2); medial margin of branchial plates short in the anterior part and convex (expressed) in posterior part (83:3).

Genera included: Ganosteus Rohon, 1901, Pycnolepis Halstead Tarlo, 1964, Pycnosteus Preobrazhensky, 1911.

Remarks. This group is characterized by two apomorphies $(64: 2,67: 4,69: 1)$. Pycnolepis is recovered as sister node to Pycnosteus. Ganosteus is sister to Pycnolepis and Pycnosteus. The genus Tartuosteus is excluded from the family Pycnosteidae, exhibiting characters (e.g. reduced shape of postorbital plates) that bring it closer to Schizosteus and Psammolepis (Fig. 3).

\section{Family Psammolepididae Tarlo, 1962}

Diagnosis (revised). Rostral plate with aligned anterior margin (4:3); tesselated dorsal plate with small non-tesselated primordium (57:2); ventral plate with lateral and posterior pattern of tesserae (71:3); branchial plates with arcuate convex anterolateral margin (82:1) and with convergently oriented distal tips (85:1).

Genera included. Psammolepis Agassiz, 1845.

Remarks. This group is characterized by apomorphies $(4: 3,71: 3)$. Psammolepis are still wide-bodied animals with the basal shape of the main plates retained, but they acquire tesserae on the dorsal and ventral plates (57:2) and oval ventral plate (67:5). Based on the results of the second analysis, Psammolepididae with Psammosteidae may be grouped in one clade of the most tesselated psammosteids on the basis of the following basic apomorphies: dorsal plate with numerous tesserae and small primordium (57:2); ventral plate with secondary convex posterior margin (67:5) and with posterior pattern of tesserae (71:2). Some species, previously grouped 
in the genus Psammolepis (see Halstead Tarlo, 1965; Obruchev and Mark-Kurik, 1965) have been moved into another clade (Psammosteidae).

\section{Psammolepis Agassiz, 1845}

Diagnosis. As for the family.

Type species. Psammolepis paradoxa Agassiz, 1844. Species included. Psammolepis abavica MarkKurik, 1965; P.paradoxa Agassiz, 1844; P.toriensis (Mark-Kurik, 1965); P. venyukovi Obruchev, 1965.

Remarks. The unique specimen of a ventral plate of Psammolepis venyukovi is poorly preserved and lacks tesserae (Obruchev and Mark-Kurik, 1965, p. 200); it is the central fragment of a ventral plate with erased margins and probably detached tesserae. Phylogenetic analyses placed 'Psammolepis' alata, ' $P$ '. proia, ' $P$ '. undulata (Halstead Tarlo, 1965; Novitskaya, 2004; Obruchev and Mark-Kurik, 1965) and true Psammolepis at different places on the tree (Fig. 2), indicating they do not belong within the same genus.

Family Psammosteidae Traquair, 1896 emend. Glinskiy

Diagnosis (revised). Dorsal plate oval/pear-shaped with narrowing front part $(30: 3 ; 31: 2)$, its lateral margins concavo-convex (33:1) and posterior margin convex (rounded) (36:1); tesselated dorsal plate with large non-tesselated primordium (57:3); ventral plate is very elongated (65:2), rooted tesserae partly covering, large primordium, not covered by tesserae (57:3); ventral plate with anterior position of primordium (70:2) and posterior pattern of tesserae (71:2) of scale-like, rhombic, or square forms without overlapped margins (72:1); medial margin of branchial plates with anteriorly concave and posteriorly expressed convex (eurybasal) (83:2); ornamentation consist of rows of ridges and tubercles (109:2); cell imprints on the surface of tubercles expressed and numerous (116:2).

Taxa included: Vladimirolepis gen. nov., subfamilies Placosteinae subfam. nov., and Psammosteinae Traquair, 1896.

Remarks. The Psammosteidae form a well-supported clade, which is characterized by the following apomorphies: 30:3, 31:2, 57:3, 65:2, 71:2, 72:1, 83:2, 116:2. Some apomorphies $(31: 2,57: 3,72: 1,83: 2)$ change within this group. The psammosteids are narrow-bodied animals (shape of median plates). The growth of median plates occurs in the caudal direction (in length). More derived taxa (Psammosteus) have an oval dorsal plate with anterolateral lobes (for the support of the branchial plates, 30:4) with ldc canals (49:1), last one indicates the reduced (or absent) fields of tesserae (Fig. 3) . Branchial plates are extended in width (the distal parts in the basal species Vladimirolepis proia comb. nov. still have such widening), bringing them closer to the Psammosteidae. Tubercles on the branchial plates of most all representatives can fuse into ridges. In later psammosteids (Placosteinae subfam. nov. and Psammosteinae), growth of tesserae was not constrained (progressive tesserization) (Obruchev and Mark-Kurik, 1965; Obruchev, 1972, p.70).

\section{Psammosteidae subfamily incertae sedis}

\section{Vladimirolepis gen. nov.}

Psammolepis Agassiz: Obruchev and Mark-Kurik, 1965, pp. 162-164 (pars), 296-297 (pars); Halstead Tarlo, 1965, pp. 95-96 (pars); Novitskaya, 2004, p. 182-183 (pars).

Tartuosteus Obruchev: Obruchev, 1961, pp. 107-108 (pars); Halstead Tarlo, 1965, p. 85 (pars).

Derivation of name. In honor of the palaeontologist Vladimir Paul, who collected (1934-1940) many unique fish remains from the Middle Devonian deposits of Estonia, and lepis, meaning scale, gender feminine.

Type species. Psammolepis proia Mark-Kurik, 1965.

Diagnosis. Dorsal plate with narrowing front part (30:3), with big primordium in anterior half of plate (55:1, 57:3), first pair of transverse commissures concave anteriorly (41:1), posterior (third) pair of tc concave anteriorly (43:1); eurybasal branchial plates with convexolinear anterolateral margin $(82: 0+3)$.

Remarks. The following unique apomorphies characterize only this most basal taxon of Psammosteidae: 30:3, 57:3. The shape of the primordium (juvenile stage of plate) of Vladimirolepis proia comb. nov. is identical to the shape of the dorsal plate of Schizosteus striatus. Also, the primordium of the ventral plate has a V-shaped posterior notch (64:1) as in the more primitive forms (Schizosteus). These characters strongly distinguish Vladimirolepis gen. nov. from Placosteus. The pattern of ornamentation with tubercles fused in ridges is similar to those in Schizosteus striatus and Placosteus.

\section{Vladimirolepis proia (Mark-Kurik, 1965), comb. nov.}

Psammolepis paradoxa Agassiz: Bystrow, 1955, pp.499505, Figs. 26-29, 33-34.

Tartuosteus giganteus (Gross): Obruchev, 1961, pp. 108, 109 (pars), Text-figs. 1a, 3; Halstead Tarlo, 1964a, Text-figs. 12B, 16B; Halstead Tarlo, 1965, pp. 8589 (pars), Text-fig. 24A, B, D.

Psammolepis sp.: Obruchev, 1964, Text-figs. 11, 53.

Psammolepis proia Mark: Halstead Tarlo, 1964a, p. 104; Halstead Tarlo, 1964b, p. 11, Text-fig. 5.

Psammolepis proia Mark-Kurik: Obruchev and MarkKurik, 1965, pp. 164-169, 297, Text-figs. 121-127, pl. 36, Figs. 1, 2, pl. 37, Figs. 1-3; Halstead Tarlo, 1965, p. 106, 107, Text-fig. 33; Obruchev and Mark-Kurik, 1968, Figs. 1, 3B, 4; Blieck, Elliott, and Gagnier, 1991, Fig. 4M; Novitskaya, 2004, p.183, Figs. 112, 113; Elliott and 
Mark-Kurik, 2005, pp. 101, 103, Fig. 4A; Glinskiy, 2014, pp. 985, 986, 989, pl. 4, Figs. 1, 2.

Diagnosis. As for the genus.

Remarks. The specimen GIT 116-170, earlier defined as a cornual plate, is considered here as the rostral plate.

Subfamily Placosteinae subfam. nov.

Diagnosis. Dorsal plate partly covered by tesserae, with the mosaic of own superficial layer $(57: 4)$, its primordium fully covered with tesserae $(58: 1)$; rooted tesserae of dorsal plate small $(0.2-0.8 \mathrm{~cm})(59: 2)$; ventral plate with oval primordium (64:3); dorsal plate with secondarily reduced median posterior process on posterior margin (37:0).

Type genus. Placosteus, by monotypy.

Taxa included. Type genus only.

$$
\text { Placosteus, Agassiz, } 1845
$$

Placosteus Agassiz: Agassiz, 1833-1843, p.33 (nomen nudum); 1845, p. 404 (pars).

Psammosteus Agassiz: Agassiz, 1844, p.103 (pars); Eichwald, 1860, p. 1515 (pars); Woodward, 1891, p. 126 (pars).

Psammolepis Agassiz: Gross, 1933a, p. 5 (pars); 1935, p. 15 (pars); Obruchev, 1947a, p. 195 (pars); Obruchev, 1964, p.73 (pars); Obruchev and Mark-Kurik, 1965, pp.162164 (pars), 296-297 (pars); Halstead Tarlo, 1965, pp.9596 (pars); Novitskaya, 2004, pp. 182-183 (pars).

Diagnosis. Dorsal plate partly covered by tesserae, with the mosaic of own superficial layer (57:4), its primordium fully covered with tesserae $(58: 1)$; rooted tesserae of dorsal plate small $(0.2-0.8 \mathrm{~cm})$; dorsal plate with secondarily reduced median posterior process on posterior margin (37:0); (59:2); ventral plate with oval primordium (64:3).

Type species. Psammosteus undulatus Agassiz, 1844.

Species included. Type species and Placosteus alatus (Mark-Kurik, 1965).

Remarks. The two genera Vladimirolepis gen. nov. and Placosteus gen. nov. are the two early-branching members of the family Psammosteidae; they still have the eurybasal branchial plates (83:2) but strongly differ in general morphology of the juvenile median plates (primordia).

\section{Placosteus undulatus (Agassiz, 1844)}

Placosteus undulatus Agassiz: Agassiz, 1833-1843, p. 33 (nomen nudum); 1845, p. 404.

Psammosteus undulatus Agassiz: Agassiz, 1844, p. 106, pl. 31, Fig. 11, 12; 1845, p.417; Eichwald, 1860, pp. 1517, 1518 (pars); Woodward, 1891, p. 128.
Psammosteus tesselatus Traquair: Traquair, 1897, p.377, pl. 6, Fig. 1, 2.

? Psammosteus arenatus Agassiz: Doss, 1915, pp. 77, 78, pl. 2.

Psammolepis heteraster Gross: Gross, 1930, pp. 7, 14; pl. 1, Fig. 2; Gross, 1933a, p. 8; pl. 1, Fig. 2; Obruchev and Mark-Kurik, 1965, pp. 190-191, 298, pl. 50, Fig. 1, 2; Text-fig. 154; Novitskaya, 2004, pp. 185-186 (pars).

Psammolepis undulata (Agassiz): Gross, 1933a, pp. 8, 9, pl. 1, Figs. 3, 6; Gross, 1942, p.410, Text-fig. 2A; Tarlo, 1961, pp. 202-204; pl. 7, Fig. 4, 5, Text-figs. 3d, 7; Halstead Tarlo, 1964a, pp. 31, 32, 37, 38,104, 105, Text-fig. 12A; Obruchev and Mark-Kurik, 1965, pp. 201-211, 299, Text-figs. 166-175, pl. 56, Fig. 1, 2, pl. 57, Fig. 1, 2; pl. 58, Fig. 1-3; pl. 59, Fig. 1-3; pl. 60, Fig. 1-3; pl. 60, Fig. 1; pl. 74, Fig. 1 (non Psammosteus levis); Novitskaya, 1965, pp. 273-274, Fig. 219; Halstead Tarlo, 1965, pp. 103-106, Text-fig. 32, pl. 18, Fig. 2; Obruchev and Mark-Kurik, 1968, p. 282, Fig. 1, 3C, 4; Lyarskaya, 1971, pp. 98-101, Text-figs. 3-6; Novitskaya, 2004, p.187, Text-figs. 122, 123; Elliott and Mark-Kurik, 2005, pp. 101, 103, (non 100), Fig. 4B, 6A-C; Plax, 2010, pp. 64, 65, pl. 1, Figs. 4-10.

? Psammolepis undulata (Agassiz): Gross, 1935, p.15, pl. 3, Fig 4.

Psammolepis timanica Obruchev: Obruchev, 1958, p. 48 (nomen nudum).

Diagnosis. As for 'Psammolepis' undulata in Obruchev and Mark-Kurik (1965, pp. 201, 299).

Remarks. Psammolepis heteraster Gross, 1930 is considered a junior synonym of Placosteus undulatus (Halstead Tarlo, 1964a, pp. 87, 104) on the basis of morphology of branchial plates and ornamentation characters.

\section{Placosteus alatus (Mark-Kurik, 1965), comb. nov.}

Psammolepis alata Obruchev: Obruchev, 1958, p. 47 (nomen nudum); Halstead Tarlo, 1965, pp.109-111, Textfig. 35.

Psammolepis alata Mark-Kurik: Obruchev and MarkKurik, 1965, pp. 184-190, 298, Text-fig. 147-153, pl. 46, Fig 3; pl. 47, Fig. 1, 2; pl. 48, Fig. 1-3; pl. 49, Fig. 1, 2; Mark-Kurik, 1966, pp. 57, 58, pl. 2, Fig. 1, 2; Obruchev and Mark-Kurik, 1968, Fig. 1; Lyarskaya, 1971, pp. 101104, Figs. 7-9; Novitskaya, 2004, p. 185, Text-fig. 116, 117; Lebedev et al., 2009, p. 348, Fig. 2I, J, 3; Johanson et al. 2013, pp. 2-5, Fig. 1b, d-r, Fig. 2.

Diagnosis. As for 'Psammolepis' alata Mark-Kurik, 1965 in Obruchev and Mark-Kurik (1965, pp. 184, 298).

Remarks. Placosteus alatus is very similar to Pc. undulatus but differs in branchial plate shape and some ornamentation characters. The dorsal plate of Pc. alatus was possibly fully covered by tesserae. 


\section{Subfamily Psammosteinae Traquair, 1896}

Diagnosis. Median plates fully covered by tesserae (57:5), which are polygonal in shape and without overlapped margins (60:2); branchial plates shortened (stenobasal) and stretched in width (length-width ratio less than 0.6) (81:3); branchial plates medial margin with short anterior part and convex, expressed posterior part (83:3); branchial plates with expanded unornamented surface on ventral side (87:1).

Genera included. Elgaia gen. nov., Psammosteus Agassiz, 1844, Karelosteus Obruchev, 1933, Traquairosteus Halstead Tarlo, 1964.

Remarks. This group is characterized by the following basal apomorphies (57:5, 60:2). Currently this group (family Psammosteidae sensu Halstead Tarlo, 1965; Novitskaya, 2004) includes Psammosteus and provisionally retained Karelosteus (Glinskiy and Mark-Kurik, 2016; Novitskaya, 2004). Herein two more genera, Elgaia gen. nov. and Traquairosteus, are included. With the availability of new data on psammosteids, the list of their unique apomorphies must be refined. Presumably all representatives of the family Psammosteidae appear to lack cornual plates, as in the associated cephalothorax of Psammosteus megalopteryx (Woodward, 1911, pl IX, Fig. 1). Halstead Tarlo (1965, p. 121) redescribed this specimen and identified the area with isolated tubercles as the remains of the cornual plate. However, such isolated tubercles also can be attributed to numerous discrete micromeric elements or to the ornamentation, detached from the main plates (tubercles are weakly connected with the plates of Psammosteus, see Mark-Kurik, 1999). The branchial openings presumably are located behind the reduced branchial plates through the branchial sinus of the dorsal plates (Fig. 2). The characters of the Psammosteinae appear in Elgaia luhai (Mark-Kurik, 1965) comb. nov. In the species of Psammosteus, a full reduction of the anterior part of the median margin of the branchial plates is seen, and cyclomorial, mostly polygonal concentric tesserae of the basic morpho-histological type are formed (Glinskiy and Nilov, 2017). Traquairosteus should be nested closer to Psammosteus, as has been noted earlier (Glinskiy and Pinakhina, 2018; Glinskiy, 2018). In Traquairosteus the tesserae and other elements of progressive type may be rooted on the main plates, forming the strange unique ornamentation . Traquairosteus is grouped with a question with the species 'Psammosteus' ramosus Glinskiy, 2017, 'P'. pectinatus Obruchev, 1965, ' $P$ '. kiaeri Halstead Tarlo, 1964, and ' $P$ '. falcatus Obruchev in Gross, 1942, from the Upper Devonian (Frasnian) of the Main Devonian Field, Scotland and Ellesmere Island. These psammosteids have extremely stenobasal branchial plates $(\mathrm{l}: \mathrm{w} \leq 0.3)$ and discrete tesserae of the progressive morpho-histological type (odontodelike shape), which represent the circular stage of the tesserae development (Glinskiy and Nilov, 2017). Histology of the plates of these psammosteids is very similar to that of Traquairosteus pustulatus (aspidin mounds, surmounted by tubercles with massive marginal crenulations (Traquair, 1897, pl. XI, Fig. 4) and differences of tubercle shapes (Traquair, 1897, Additional notes..., pl. XI, Fig 4)).

In addition, it should be noted that in the reconstruction of Psammosteus by Halstead Tarlo (Tarlo, 1961, Fig. 5), the proximal parts of the branchial plates are freely located in the cephalothorax. According to this author's opinion, Psammosteus has movable branchial plates (Halstead, 1973, p.291). However, numerous specimens of Psammosteus branchial plates with the strong marginal lifetime abrasion on the substrate indicate the fixed location of these plates in the cephalothorax. The medial parts of Psammosteus branchial plates definitely grew under anterolateral lobes of the dorsal plate.

\section{Elgaia, gen. nov.}

Tartuosteus: Obruchev: Obruchev, 1964, pp.71-72 (pars); Halstead Tarlo, 1965, pp. 85 (pars); Obruchev and Mark-Kurik, 1968, pp. 280 (pars).

Tartuosteus ? Obruchev: Obruchev and Mark-Kurik, 1965, pp.110-111 (pars), 293 (pars); Novitskaya, 2004, pp. 174-175 (pars).

Derivation of name. In memory of Elga MarkKurik, Estonian palaeontologist and stratigrapher, gender feminine.

Diagnosis. Dorsal plate fully covered by dense rooted tesserae (57:5); branchial plates shortened (stenobasal) and stretched in width (81:3); their medial margin with short anterior part and convex, expressed posterior part (83:3); branchial plates with expanded unornamented surface on ventral side of plates (87:1).

Type species. Tartuosteus luhai Mark-Kurik, 1965.

Remarks. Tesserae are not known in the median plates of Tartuosteus species (Elliott and Mark-Kurik, 2005, p. 101), the dorsal and branchial plates of Elgaia gen. nov. are different from those of Tartuosteus. This new genus is the most basal representative of the subfamily Psammosteinae and differs from Psammosteus by the relative length and shape of branchial plate medial margin (83:3) and mostly scale-like, dense rooted tesserae on the dorsal plate $(60: 1+2,62: 0)$.

Elgaia luhai (Mark-Kurik, 1965), comb. nov. Fig. 4

Tartuosteus luhai Mark: Obruchev, 1958, p. 46 (nomen nudum); Obruchev, 1961, pp. 108, 110.

Tartuosteus luhai Mark-Kurik: Halstead Tarlo, 1964a, p. 103, 105; Halstead Tarlo, 1965, pp. 89-90, Text-fig. 26. Tartuosteus ? luhai Mark-Kurik: Obruchev and MarkKurik, 1965, pp.111, 129-131, 294, Text-figs. 76, 77; 
pl. 23, fig. 3, pl. 24, fig. 4; Obruchev and Mark-Kurik, 1968, p. 280, 282, fig. 1; Novitskaya, 2004, p. 177, fig. 102.

Diagnosis. As for the genus.

Remarks. The dorsal plate of E. luhai (Mark-Kurik, 1965), comb. nov., is completely covered by scale-like, cyclomorial tesserae with eccentric position of the primordial tubercles (Fig. 4 G-I), they are consolidated with aspidin layer. A few cyclomorial tesserae are with concentric position of the primordial tubercles as in Psammosteus (Fig. $4 \mathrm{G}$ ). Branchial plates are stenobasal (Fig. 4 A, B, E, F) with length/width ratio 0.6.

\section{Psammosteus Agassiz, 1844}

Diagnosis (revised). Dorsal plate (and other main plates) with weak rooting of bases of rooted tesserae (62:1); shape of medial margin of stenobasal branchial plates expressed convex (83:4); rooted tesserae mostly polygonal (60:2). 1844.

Type species. Psammosteus maeandrinus Agassiz,

Species included: P. bergi (Obruchev, 1943); P. maeandrinus Agassiz, 1844; and P.praecursor Obruchev, 1947. Provisionally included species: Psammosteus asper Obruchev, 1965; P. cuneatus Obruchev, 1965; P. levis Obruchev, 1965; P.livonicus Obruchev, 1965; P. megalopteryx (Trautschold, 1880); and P. tenuis Obruchev, 1965.

Remarks. Currently, there is no way to divide the genus Psammosteus into several genera, as there is not enough information on the median plates of many species, their natural margins and interspecific variation. The different morphologies of the juvenile and adult branchial plates and the morpho-histological types of tesserae (Glinskiy and Nilov, 2017) suggest several evolutionary lines (potentially genera). The first group (P. bergi, P.precursor, P.maeandrinus; Fig. 2) has triangular branchial plates with an oblique margin of ornamentation on their dorsal side (Psammosteus); the second group (all other species provisionally included in Psammosteus + Karelosteus weberi Obruchev 1933) has extremely stenobasal branchial plates (81:4) and small zones of ornamentation (87:2). According to the results of phylogenetic analysis, Karelosteus weberi Obruchev 1933 is included in the Psammosteus clade. However, the genus Karelosteus is provisionally retained, because it is not known how many species of the large Psammosteus clade will be divided into several genera following a future analysis of all available material. Psammosteus livonicus was described in Oredezhosteus (Moloshnikov, 2009), and later this genus was revised (Glinskiy and Mark-Kurik, 2016). Possibly, in the future P. livonicus and the related species P. asper might be included also in Karelosteus. The current analysis included corrected data on the dorsal plate of Psammosteus livonicus, which should be expanded by the narrowed part in the caudal direction (error orientation: Mark-Kurik 1968, Fig. 11A; Elliott and Mark-Kurik 2005, Fig. 4 F).

\section{Traquairosteus Halstead Tarlo, 1964}

Psammosteus Agassiz: Obruchev, 1947b, pp.517-518 (pars), Obruchev, 1964, p.74 (pars); Obruchev and Mark-Kurik, 1965, pp.215-219 (pars), 299 (pars); Halstead Tarlo, 1965, pp.114-115 (pars); Novitskaya, 2004, p. 189 (pars); Glinskiy and Mark-Kurik, 2016, p. 5 (pars). Traquairosteus Halstead Tarlo: Halstead Tarlo, 1964a, p.117; Halstead Tarlo, 1965, p.150; Halstead, 1969, p. 118; Glinskiy and Pinakhina, 2018, p. 83.

Diagnosis (revised). Discrete micromeric elements with aspidin mounds, surmounted by tubercles (progressive morpho-histological type) and main plates with peculiar morpho-histological structure (108:4, 119:1); tubercles with very complete marginal crenulations (branching tips and branching on the entire length of crenulations) (114:4).

Type species. Traquairosteus pustulatus (Traquair, 1897).

Species included: Traquairosteus pustulatus (Traquair, 1897) ? = Traquairosteus $?$ falcatus (Obruchev in Gross, 1942); T. ? kiaeri (Halstead Tarlo, 1964); T. ? pectinatus (Obruchev, 1965); and T.? ramosus (Glinskiy, 2017).

Remarks. This group is characterized by the following apomorphies: 108:4, 114:4. This terminal group of psammosteids has extremely stenobasal branchial plates (like other derived psammosteids) with large tubercles that are located on aspidin mounds (detailed histological and topographic comparisons are needed; this work is held jointly with D. K. Elliott). Widely spaced tubercles on the median plates of Traquairosteus should be interpreted as rooted progressive micromeric elements (Glinskiy and Nilov, 2017) as on the dorsal plate of Traquairosteus? falcatus (Obruchev and Mark-Kurik, 1965, p. 66, pl. 88, Fig. 2). The holotype of Traquairosteus pustulatus probably has imprints from the detached tesserae. Apparently Traquairosteus pustulatus and Traquairosteus? falcatus Obruchev in Gross, 1942 are the same species named on different exoskeleton plates. Differences in the ornamentation of Traquairosteus pustulatus might be a consequence of topographic variability (branchial plates with complicated ornamentation in contrast to median plates with simple ornamentation) and different conditions of preservation between the locality of Scaat Craig (Scotland) and the Main Devonian Field. The described elongated plate (Tarlo, 1961, Fig. 6) of T.pustulatus is probably the ventral plate.

Psammosteidae family incertae sedis 'Schizosteus' perneri (Růžička, 1929)

Diagnosis. As the species description given by Vaškaninová and Kraft (2016). 

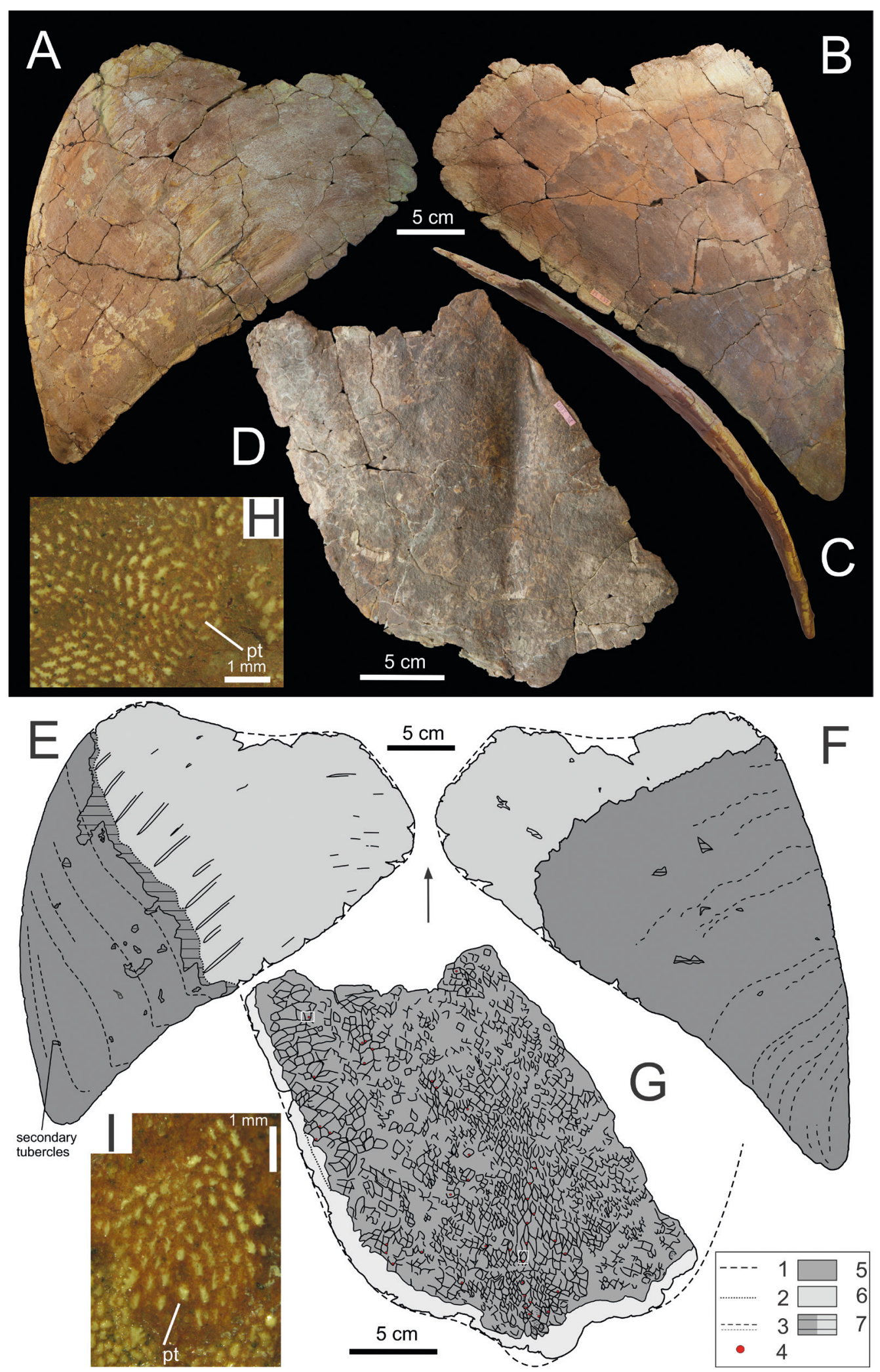

Fig. 4. Elgaia luhai (Mark-Kurik, 1965) comb. nov., branchial and dorsal plates from the Aruküla Regional Stage, (Givetian, Middle Devonian) of Estonia. A-C, E, F, GIT 116-112, holotype, left branchial plate, Mõra outcrop, coll. V. Paul, 1940; A, E, dorsal, B, F, ventral and C, anterolateral views; D, G, H, I, GIT 116-113, dorsal plate, Mõra outcrop, coll. V. Paul, 1934, D, G, general dorsal view, H, I, shots of tesserae are shown in Fig. 4 G (white squares). Abbreviations: arrow indicates the anterior direction, white frames on the Fig. $4 \mathrm{G}$ indicates the shots Fig. $4 \mathrm{H}$, I; 1 , supposed contour line of the plates; 2 , supposed margin of the ornamented surface; 3 , growth line; 4, primordium tubercle of tesserae (pt); 5 , ornamented surface; 6 , unornamented surface; 7 , destroyed parts of the plate. The differences of the branchial plates' length-width ratio in dorsal and ventral views (as seen on this figure) is associated with their dorsally convex shape in the transverse-longitudinal direction. 
Remarks. 'Schizosteus' perneri (Růžička) might be attributed to guerichosteids on the basis of the presence of the typical ornamentation (fairly smooth margins of tubercles without marginal crenulations ) and extremely narrow branchial plates. However, the branchial plates of this species have lost the dorsal lamella (79:4) and have more isometric eurybasal shape (81:1); the derived Middle Devonian psammosteids have such synapomorphies. Obruchev and Mark-Kurik (1965, p.15) stated that ' $S$ '. perneri should be attributed to the more basal genus (close to Drepanaspis) and did not include this species in the genus Schizosteus. Ornamentation of branchial plate 'S.' perneri (holotype) is fairly abraded (Vaškaninová and Kraft, 2016, pl. 1, Figs. 2d-f). The limits of variation in the ornamentation on the ventral side of plate are unknown. More data on 'S'. perneri are needed. Furthermore it is necessary to postpone naming of a new genus for 'S. ' perneri until the new information on the problematic 'psammosteid-like' genus Sedowichthys and the dorsal side of the branchial plate of 'Hariosteus' becomes known. In any case, the guerichosteids and 'Schizosteus' perneri are the early branching lineages derived from the basal psammosteids.

\section{Schizosteus Obruchev, 1940}

Diagnosis (revised). Dorsal plate with convex (rounded) posterior margin (35:2); ventral plate with middle sized posterior notch (L1/L2 $=0.3-0.5)(68: 1)$; tubercles with small $(0.3-0.7 \mathrm{~mm})$ dominant sizes of bases (111:1); tubercles surfaces with poorly visible cell imprints (116:1).

Type species. Schizosteus asatkini Obruchev, 1940.

Species included. S.asatkini Obruchev, 1940, Schizosteus striatus Gross, 1933.

Remarks. Psammosteids with long and narrow branchial plates. Monophyly of the genus Schizosteus is not supported due to the lack of data on the central (median) plates of the adult specimens of S.asatkini and S. striatus. Thus, it is unknown whether the character 32:1 (straight anterior margin of the dorsal plate) describes only Schizosteus striatus, or both species of Schizosteus. To clarify the position of Schizosteus asatkini Obruchev, 1940, the specimens of Schizosteus ? sp. (Glinskiy, 2014) were included, which are probably worth attributing to this species. Pycnolepis splendens (Eichwald, 1844) was previously attributed to the genus Schizosteus (Novitskaya, 2004; Obruchev and MarkKurik 1965). The validity of the genus Pycnolepis Halstead Tarlo, 1964 is supported on the results of this phylogenetic analysis, and it is placed in the clade Pycnosteidae. 'Schizosteus' perneri (Růžička, 1929) is attributed here to the basal evolution line of psammosteids that is close to guerichosteids.

\section{Tartuosteus Obruchev, 1961}

Diagnosis (revised). Branchial plates are wide, eurybasal (length-width ratio more than 0.6 ) with a straight anterolateral margin (82:3) and wide ornamented surface (more less 1) on the dorsal side (86:2).

Type species. Tartuosteus giganteus (Gross, 1933).

Species included. Tartuosteus giganteus (Gross, 1933); Tartuosteus maximus Mark-Kurik, 1965.

Remarks. The current analysis includes only two species of this genus with a generally triangular shape of the branchial plates. Tartuosteus? (Rohonosteus) ornatus (Rohon, 1899) and T. ?zheleznogorskensis Moloshnikov, 2009 are not considered here due to the poor material. The unique specimen of the last species is possibly Psammosteus with pathology of branchial plate development and imprints of detached tesserae on ventral side. Elgaia luhai (Mark-Kurik, 1965) comb. nov. is placed in the clade Psammosteidae as the basal taxon. Tesserae are not known in the main plates of Tartuosteus species (Elliott and Mark-Kurik, 2005, p. 101). Tartuosteus and Psammolepis have a synapomorphy - their postorbital plates do not have the posterior process (24:3).

\section{Discussion and conclusions}

The results of the analyses show that psammosteids belong to the Pteraspidiformes. The derived pteraspids (Pteraspidoidei sensu Pernègre and Elliott, 2008 with Doryaspididae Heintz in Tarlo, 1962) form the sister group for the psammosteids. Results of both analyses indicate that psammosteids originate from the basal pteraspidiformes as Protopteraspis (Blieck, Elliott, and Gagnier, 1991). These results contradict a hypothesis that some pteraspids, representatives of Doryaspididae Heintz in Tarlo, 1962, must be united in one clade with psammosteids (Pernègre, 2002; Randle and Sansom, 2016, 2017). The present analyses do support the classically accepted monophyly of psammosteids (suborder Psammosteoidei sensu Psammosteida Kiaer, 1932 emend. Tarlo, 1962) and for the most part the classical arrangement of families: Drepanaspididae; Guerichosteidae; Obrucheviidae; Pycnosteidae; Psammolepididae; and Psammosteidae. This study provides a basis for a deeper investigation into the intra-relationships of the psammosteids. The ingroup taxa have been chosen to represent only the best and most completely known genera. During the analysis the monophyly of some psammosteid genera (e.g. Schizosteus, Tartuosteus, Pycnosteus, Psammolepis) and validity of doubtful taxa (e.g. Pycnolepis splendens) were checked. From the genus Psammolepis sensu Obruchev and MarkKurik, 1965, Halstead Tarlo, 1965, are excluded taxa Vladimirolepis proia comb. nov., Placosteus undulatus and Placosteus alatus comb. nov. From Tartuosteus sensu Obruchev and Mark-Kurik, 1965, Halstead Tarlo, 1965 is 
excluded Elgaia luhai comb. nov. Elgaia gen. nov. is the most basal taxon of the subfamily Psammosteinae. Two new subfamilies (Placosteinae subfam nov. and Psammosteinae Traquar, 1896) are erected. Also proposed is inclusion of a number of 'Psammosteus' species with progressive types of tesserae and peculiar histological structure of other plates in the genus Traquairosteus (Glinskiy and Pinakhina, 2018; Glinskiy, 2018). Guerichosteus, Schizosteus and Psammosteus are still very poorly known by median plates and represent here a paraphyletic groups (additional material is needed). New material on the median plates of these taxa and Karelosteus is needed for a more correct analysis. The following taxa, used in the analysis, are not assigned to the existing families (Psammosteoidei incertae sedis): 'Schizosteus' perneri (Růžička, 1929); Schizosteus Obruchev, 1940; Tartuosteus Obruchev, 1961.

\section{Acknowledgements}

I am grateful to supervisior A. Ivanov (St. Petersburg State University), U. Toom (Department of Geology at Tallinn University of Technology) and I. Zupinš (Natural History Museum of Latvia) for assistance and for providing access to the psammosteid collections, and to A. Blieck (University of Lille), D. Elliott (Northern Arizona University) and M. Wilson (University of Alberta) for the useful discussions, constructive reviews and improvement of English. The author thanks D. Pinakhina (St. Petersburg State University) and J. Boyle (Biological Communications journal) for helping with translation and linguistical corrections. I express my gratitude to editor N.Zelenkov (Borissiak Paleontological Institute of the Russian Academy of Sciences), P. Skutschas, I. Kuzmin (Saint Petersburg State University), L. Lassiter (Northern Arizona University), M. Sinitsa (Ural Federal University) and especially A. Averianov (Zoological Institute of Russian Academy of Sciences) for their advice and help with phylogenetic analysis. I am obliged to N. Vlasenko, V. Shilovskikh and S. Nilov (Research Park of St. Petersburg State University) for their great help with SEM photographs and tomography.

\section{References}

Agassiz, L. 1833-1843. Recherches sur les Poissons fossiles. Tableau général des Poissons fossiles, rangés par terrains, vol. 1. Neuchâtel.

Agassiz, L. 1844. Monographie des Poissons fossiles du vieux grè s rouge ou système Dévonien (Old Red Sandstone) des Isles Britanniques et de Russie. Neuchâtel: Jent \& Gaßmann (Solothurn).

Agassiz, L. 1845. Lettres sur les Poissons fossiles du système Dévonien de la Russie; pp. 397-418 in Murchison, R. I., de Verneuil, E. \& A. de Keyserling, C. A. Géologie de la Russie d'Europe et des montagnes de l'Oural, vol. 2. Paris.

Berg, L. S. 1937. A classification of fish-like vertebrates. Izvestiya Akademii Nauk SSSR (Bulletin of the Academy of Sciences of the USSR). Otdelenie matematicheskikh i estestvennykh nauk, seriya biologicheskaya:1277-1280.

Berg, L. S. 1940. Sistema ryboobraznykh i ryb, nyne zhivushchikh i iskopaemykh [Classification of fishes, both recent and fossil]. Trudy Zoologicheskogo Instituta Akademii Nauk SSSR 5(2):87-517.

Berg, L. S. 1955. Sistema ryboobraznykh i ryb, nyne zhivushchikh i iskopaemykh [Classification of fishes, both recent and fossil]. Trudy Zoologicheskogo Instituta Akademii Nauk SSSR 20:1-289.
Blieck, A. 1984. Les Hétérostracés Ptéraspidiformes, agnathes du Silurien-Dévonien du continent Nord-Atlantique et des blocs avoisinants: revision systématique, phylogénie, biostratigraphie, biogéographie. Paris: Cahiers de Paléontologie (section Vertébrés), éditions du CNRS.

Blieck, A. 1991. Reappraisal of the heterostracans (Agnathan vertebrates) of Northern Ireland. Irish Journal of Earth Sciences 11:65-69.

Blieck, A. R. M., Elliott, D. K., and Gagnier, P.-Y.1991. Some questions concerning the phylogenetic relationships of heterostracans, Ordovician to Devonian jawless vertebrates; pp. 1-17 in C. Mee-Mann, L. Yu.-hai and G. Zhang (eds), Early vertebrates and related problems of evolutionary biology. Beijing: Science Press.

Brotzen, F. 1936. Beiträge zur Vertebratenfauna des westpodolischen Silurs und Devons. I. Protaspis arnelli n. sp. und Brachipteraspis n. gen. latissima Zych. Arkiv för Zoologi 28A (22):1-52.

Bystrow, A.P.1955. Mikrostruktura pantsyrya beschelyustnykh pozvonochnykh silura i devona [Microstructure of the armor of the jawless vertebrates from Silurian and Devonian]; pp. 472-523 in E. M. Murzaev (ed.), Pamyati akademika L. S. Berga. Sbornik rabot po geografii i biologii. Publishing of AN USSR, Moscow-Leningrad.

Bystrow, A. P. 1959. The microstructure of skeleton elements in some vertebrates from Lower Devonian deposits of the USSR. Acta Zoologica 40:59-83.

Denison, R. H. 1968. Middle Devonian fishes from the Lemhi Range of Idaho. Fieldiana Geology 16:269-287.

Doss, B. 1915. Ein Fund von Psammosteus arenatus Ag. bei Wenden in Livland. Korrespondenzblatt des Naturforscher - Vereins zu Riga 57:77-78.

Eichwald, E. 1860. Lethaea Rossica, ou Paléontologie de la Russie, décrite et figurée. Premier Volume. Ancienne periode. Stuttgart: E. Schweizerbart.

Elliott, D. K. 1984. A new subfamily of the Pteraspididae (Agnatha, Heterostraci) from the Upper Silurian and Lower Devonian of Arctic Canada. Palaeontology 27:169-197.

Elliott, D. K., and Mark-Kurik, E. 2005. A review of the lateral line sensory system in psammasteid heterostracans. Revista Brasileia de Paleontologia 8:99-108.

Elliott, D., Mark-Kurik, E., and Daeschler, E. B. 2004. A revision of Obruchevia (Psammosteida: Heterostraci) and the description of a new obrucheviid from the Late Devonian of the Canadian Arctic. Acta Universitatis Latviensis 679:22-45.

Glinskiy, V. N. 2014. New records of psammosteids (Heterostraci) from the Aruküla Regional Stage (Middle Devonian) of the Leningrad Region, Russia. Paleontological Journal 48:980-991. https://doi.org/10.1134/ S0031030114090032

Glinskiy, V. 2017. Evolutionary lineages in the family Psammosteidae (Agnatha: Pteraspidiformes): pp. 39-40, in Ginter, M. (ed.), 14th International Symposium on Early and Lower Vertebrates (Cheçiny, Poland, 2017). Ichthyolith Issues, Special Publication, 13.

Glinskiy, V.2018. Resul'taty analiza filogeneticheskikh svjazej devonskykh psammosteidnykh beschelyustnykh (Pteraspidiformes: Psammosteida). [Results of analysis of the phylogenetic relationships of the Devonian psammosteid agnathans (Pteraspidiformes: Psammosteida)]: pp. 189-190, in Bogdanova, T. M. et al. (eds), Fundamental'naya i prikladnaya paleontologija. Materialy LXIV sessii Paleontologicheskogo obshestva (Saint Petersburg, Russia, 2-6 April, 2018).

Glinskiy, V. N., and Mark-Kurik, E. 2016. Revision of Psammosteus livonicus Obruchev (Agnatha, Heterostraci) from the Devonian Amata Regional Stage of the NW of the 
East European Platform. Estonian Journal of Earth Sciences 65:1-18. https://doi.org/10.3176/earth.2016.02

Glinskiy, V. N., and Nilov, S. P. 2017. A new psammosteid (Agnatha, Heterostraci) from the Amata Regional Stage of the Main Devonian Field and morpho-histological types of discrete micromeric elements in the family Psammosteidae. Estonian Journal of Earth Sciences 66:59-76. https://doi.org/10.3176/earth.2017.05

Glinskiy, V. N., and Pinakhina, D. V. 2018. New data on psammosteid heterostracans (Pteraspidomorpha) and acanthodians (Acanthodii) from the Pärnu Regional Stage (Lower Eifelian, Middle Devonian) of Estonia. Estonian Journal of Earth Sciences 67:76-87. https://doi.org/10.3176/earth.2018.05

Goloboff, P. A. 2014. Extended implied weighting. Cladistics 30: 260-272. https://doi.org/10.1111/cla.12047

Goloboff, P. A., Farris, J. S. and Nixon, K. C. 2008. Cladistics TNT, a free programm for the phylogenetic analysis. Cladistics 24: 774-786. https://doi.org/10.1111/j.10960031.2008.00217.x

Gross, W. 1930. Die Fische des mittleren Old Red Süd-Livlands. Geologische und Palaeontologische Abhandlungen 22 (N. F. 18):123-156.

Gross, W. 1933a. Die Fische des Baltischen Devons. Palaeontographica 79A:1-74.

Gross, W.1933b. Die phylogenetische Bedeutung der altpaläozoischen Agnathen und Fische. Paläontologische Zeitschrift 15:102-137.

Gross, W. 1935. Histologische Studien am Aussenskelett fossiler Agnathen und Fische. Palaeontographica 83A:1-60.

Gross, W. 1942. Die Fischfaunen des baltischen Devons und ihre biostratigraphische Bedeutung. Korrespondenzblatt des Naturforscher-Vereins zu Riga 64:373-436.

Gross, W. 1937a. Die Wirbeltiere des rheinischen Devons. Teil I. Abhandlungen der Preußischen Geologischen Landesanstalt Neue Folge:1-81.

Gross, W. 1937b. Die Wirbeltiere des rheinischen Devons. Teil II. Abhandlungen der Preußischen Geologischen Landesanstalt Neue Folge:1-83.

Gross, W. 1963. Drepanaspis gemuendenensis Schlüter. Neuuntersuchung. Palaeontographica. Abteilung A 121 (4-6):133-155.

Gross, W. 1967. Bemerkungen zum System und zur Phylogenie der Agnathen und Fische. Colloques Internationaux du Centre National de la Recherche Scientifique. Problèmes actuels de paléontologie (Évolution des vertébrés) 163:73-79.

Halstead, L. B. 1969. Calcified tissues in the earliest vertebrates. Calcified Tissue Research 3:107-124.

Halstead, L. B. 1973. The heterostracan fishes. Biological reviews of the Cambridge Philosophical Society 48:279-332.

Halstead, L. B. 1993. Agnatha; pp. 573-581 in M.J. Benton. The Fossil Record 2. London: Chapmann \& Hall.

Halstead Tarlo, L. B. 1964a. Psammosteiformes (Agnatha) A review with descriptions of new material from the Lower Devonian of Poland. I. General part. Palaeontologia Polonica $13: 1-135$.

Halstead Tarlo, L. B. 1964b. The origin of bone; pp. 3-17 in H.J.J. Blackwood, ed. Bone and Tooth: Proceedings of the First European Symposium held at Somerville College, Oxford, April 1963. Oxford: A Pergamon Press Book.

Halstead Tarlo, L. B. 1965. Psammosteiformes (Agnatha) - A review with descriptions of new material from the Lower Devonian of Poland. II. Systematic part. Palaeontologia Polonica $15: 1-168$.

Ilyes, R. R., and Elliott, D. K. 1994. New Early Devonian pteraspidids (Agnatha, Heterostraci) from East-Central Nevada. Journal of Paleontology 68:878-892.

Janvier, P. 1996. Early Vertebrates. Oxford and New York: Clarendon Press (Oxford University Press).
Johanson, Z., Smith, M., Kearsley, A., Pilecki, P., Mark-Kurik, E., and Howard, C. 2013. Origins of bone repair in the armour of fossil fish: response to a deep wound by cells depositing dentine instead of dermal bone. Biology Letters 9:1-5. http://doi.org/10.1098/rsbl.2013.0144

Keating, J.N., Marquart, C. L., and Donoghue, P.C.J. 2015. Histology of the heterostracan dermal skeleton: insight into the origin of the vertebrate mineralised skeleton. Journal of morphology 276:657-680. https://doi.org/10.1002/jmor.20370

Kiaer, J. 1932. The Downtonian and Devonian vertebrates of Spitsbergen. IV. Suborder Cyathaspida. A preliminary report edited by A. Heintz. Skrifter om Svalbard og Ishavet $52: 1-26$

Lebedev, O.A., Mark-Kurik, E. Y., Karatajūtè-Talimaa, V. N., Lukševičs, E. V., and Ivanov, A. O. 2009. Bite marks as evidence of predation in early vertebrates. Acta Zoologica 90 (Suppl. 1):344-356. https://doi.org/10.1111/j.14636395.2008.00344.x

Lyarskaya, L. A.1971. Novye nakhodki ostatkov psammosteid iz shvyantojskogo gorizonta Latvii [New finds of psammosteid remains from the Šventoji Formation of Latvia]; pp. 97-104 in A. A. Grigelis (ed.), Paleontologiya i stratigraphiya Pribaltiki i Belorussii. Sbornik 3. Mintis, Vilnius.

Mark, E. Y. 1955. Psammosteidy (Agnatha) tartuskogo i gaujskogo gorizontov devona Estonskoj SSR [Psammosteids (Agnatha) from Tartu and Gauja formations of Devonian deposits of Estonian SSR], Tallinn.

Mark-Kurik, E. Y. 1966. O nekotorykh povrezhdeniiakh ekzoskeleta psammosteid (Agnatha). [On the some injuries of the exoskeleton of the psammosteids (Agnatha)]; pp. 55-60 in R. G.W. Hecker (ed.), Organism i sreda v geologicheskom proshlom. Nauka, Moskow.

Mark-Kurik, E. 1968. New finds of psammosteids (Heterostraci) in the Devonian of Estonia and Latvia. Proceedings of the Estonian Academy of Sciences. Chemistry \& Geology 17:409-424.

Mark-Kurik, E. 1993. Notes on the squamation in psammosteids. Modern Geology 18:107-114.

Mark-Kurik, E. 1999. Psammosteid microremains from the Middle Devonian (Givetian) of Estonia. Modern Geology 24:1-21.

Moloshnikov, S.V. 2001. New data on Pycnosteus palaeformis Preobrazhensky (Heterostraci, Psammosteiformes) from Aruküla deposits of Leningrad Region. Paleontological Journal 35(4):410-414.

Moloshnikov, S.V. 2009. Oredezhosteus, a new psammosteid genus (Heterostraci, Psammosteiformes) from the Lower Frasnian (Upper Devonian) of the Main Devonian Field. Paleontological Journal 43(2):197-200. https://doi.org/10.1134/S0031030109020117

Novitskaya, L. I. 1965. Mikrostroenie nekotorykh Psammosteida [Microstructure of some Psammosteida]; pp. 257282 in D. V. Obruchev, E. Y. Mark-Kurik, Psammosteidy (Agnatha, Psammosteidae) devona SSSR [Devonian $\mathrm{p}$ sammosteids (Agnatha, Psammosteidae) of the USSR]. Tallinn: Institute of Geology, Academy of Sciences of the Estonian SSR.

Novitskaya, L. I. 2004. Podklass Heterostraci [Suborder Heterostraci]; pp. 69-207 in L. I. Novitskaya, (ed.), Fossil vertebrates of Russia and adjacent countries. Agnathans and early fishes. GEOS, Moscow.

Obruchev, D.V.1940. O nekotorykh psammosteidakh Leningradskogo i Pribaltijskogo srednego devona. [On some psammosteids from the Devonian of Leningrad district and Baltic States]. Doklady Akademii Nauk SSSR 28 (8):766-768. 
Obruchev, D. V. 1941. Ostatki Aspidosteus gen. nov. (Heterostraci) iz verkhnego devona r. Lovati [Remains of Aspidosteus gen. nov. (Heterostraci) from the Upper Devonian of Lovat' River]. Trudy Paleontologicheskogo Instituta 8 (4):7-22.

Obruchev, D.V.1943a. Yoglinia n.g., latest pteraspid from the Middle Devonian of the Leningrad District. Comptes Rendus (Doklady) de l'Académie des Sciences de I'URSS 41 (1):41-43.

Obruchev, D. V.1943b. Novaya rekonstrukcija Drepanaspis [The new reconstruction of Drepanaspis]. Doklady Akademii Nauk SSSR 43 (6):269-272.

Obruchev, D. V. 1943c. Psammosteidae devona SSSR i Spitsbergena i evolyutsiya Agnatha [Psammosteidae from the Devonian of USSR and Spitsbergen and evolution of Agnatha]. Biological Department of the Academy of Sciences of USSR. Moskow.

Obruchev, D. V. 1945. Evolutsija Agnatha [The Evolution of Agnatha] Zoological Zhournal 24:257-271.

Obruchev, D. V. 1947a. Tip Chordata. Khordovye. Podtip Vertebrata. Pozvonochnye [Phylum Chordata. Chordates. Subphylum Vertebrata. Vertebrates]; pp. 191-206 in D. Nalivkin, (ed.), Atlas of the guide forms of the fossil faunas of the USSR. Volume III. Devonien, vol. 3. State Editorial Office for Geological Literature USSR Ministry of Geology, Moskow-Leningrad.

Obruchev, D. V. 1947b. O rode Psammosteus (Heterostraci) [About genus Psammosteus (Heterostraci)]. Doklady Akademii Nauk SSSR 56 (5):517-520.

Obruchev, D. V. 1958. K biostratigrafii ikhtiofaun nizhnego i srednego paleozoya SSSR [To the biostratigraphy of the ichthyofauna of the Lower and Middle Paleozoic USSR]. Sovetskaya Geologiya 11:40-53.

Obruchev, D. V.1961. Rod Tartuosteus (Psammosteidae) iz srednego devona Pribaltiki [Genus Tartuosteus (Psammosteidae) from the Middle Devonian of Baltic States]. Paleontological Journal 2:107-111.

Obruchev, D. V.1964. Vetv' Agnatha. Beschelyustnye [The ramus Agnatha. Jawless vertebrates]; pp.34-116 in D. V. Obruchev (ed.), Osnovy paleontologii. Beschelyustnye, ryby. Basics of Palaeontology. Jawless Vertebrates, Fisches, vol. 11. Nauka, Moscow.

Obruchev, D. V. 1967. On the evolution of the Heterostraci. Colloques Internationaux du Centre National de la Recherche Scientifique. Problèmes actuels de paléontologie (Évolution des vertébrés) 163:37-43.

Obruchev, D. V. 1968. Ob evolyutsii Heterostraci [On the evolution of Heterostraci]; pp. 21-23 in D. V. Obruchev, (ed.), Essays on phylogeny and taxonomy of fossil fishes and agnathans. Nauka, Moscow.

Obruchev, D. V.1972. Nekotorye kriterii filogeneticheskikh issledovanij na primere nizshikh pozvonochnykh [Some criteria of phylogenetic studies on the example of lower vertebrates]. Paleontological Journal 3:56-70.

Obruchev, D. V., and Mark-Kurik, E. Yu. 1965. Devonian psammosteids (Agnatha, Psammosteidae) of the USSR. Tallinn: Institute of Geology, Academy of Sciences of the Estonian SSR.

Obruchev, D. V., and Mark-Kurik, E. 1968. On the evolution of the psammosteids (Heterostraci). Proceedings of the Academy of Sciences of the Estonian SSR, Chemistry \& Geology 17:279-284.

$\varnothing$ rvig, T.1961. Notes on some early representatives of the Drepanaspida (Pteraspidomorphi, Heterostraci). Arkiv för Zoologi 2(12) 12:515-535.

Pernègre, V. N. 2002. The genus Doryaspis White (Heterostraci) from the Lower Devonian of Vestspitsbergen, Svalbard. Journal of Vertebrate Paleontology 22(4):735-746.

Pernègre, V. N., and Elliott, D. K. 2008. Phylogeny of the Pteraspidiformes (Heterostraci), Silurian-Devonian jawless vertebrates. Zoologica Scripta 37(4):391-403. http://dx.doi.org/10.1111/j.1463-6409.2008.00333.x

Pernègre, V., and Goujet, D. 2007. The genus Gigantaspis Heintz, 1962 (Vertebrata, Heterostraci) from the Lower Devonian of Spitsbergen. Palaeontology 50 (2):323-346.

Plax, D. P. 2010. Rannefrnskaya ikhitofauna severa Belarusi [Lower Frasnian ichthyofaunal from the North of Belarus]. Litasfera 1(32):60-81.

Randle, E., and Sansom, R. S. 2016. Exploring phylogenetic relationships of Pteraspidiformes heterostracans (stem-gnathostomes) using continuous and discrete characters. Journal of Systematic Palaeontology 14:1-17. https://doi.org/10.1080/14772019.2016.1208293

Randle, E., and Sansom, R. S. 2017. Phylogenetic relationships of the 'higher heterostracans' (Heterostraci: Pteraspidiformes and Cyathaspididae), extinct jawless vertebrates. Zoological Journal of the Linnean Society, 14:1-17. https://doi.org/10.1093/zoolinnean/zlx025

Růžička, R. 1929. Psammosteus (Ganosteus) perneri n. sp. Příspěvek ku poznáni ryb českého paleozoika.Vestnik Státního Geologického Ústavu Čsl. Republiky 5:1-7.

Stensiö, E. A. 1927. The Downtonian and Devonian vertebrates of Spitsbergen. Part I. Family Cephalaspidae. Skrifter Svalbard Nordishavet 12:1-391.

Stensiö, E. A.1958. Les cyclostomes fossiles ou ostracodermes; pp. 173-425 in P.-P. Grassé, (ed.), Traité de Zoologie, vol. 13:1. Masson, Paris.

Tarlo, L. B. 1957. A preliminary note on new ostracoderms from the Lower Devonian (Emsian) of Central Poland. Acta Palaeontologica Polonica 11:225-233.

Tarlo, L. B. 1961. Psammosteids from the Middle and Upper Devonian of Scotland. The Quarterly Journal of the Geological Society of London 117:193-213.

Tarlo, L. B. 1962. The classification and evolution of the Heterostraci. Acta Palaeontologica Polonica 7:249-290.

Tarlo, L. B. H. 1967. Agnatha (Part II: Documentation of the fossil record); pp. 629-636 in W. B. Harland et al. (eds), The Fossil Record. Geological Society of London, London.

Traquair, R. H. 1896. The extinct vertebrate animals of the Moray Firth Area; pp. 235-285 in Harvie-Brown, J. A. and Buckley, T. E. (eds), A vertebrate fauna of the Moray Basin. Vol. 2. Edinburgh: David Douglas.

Traquair, R. H. 1897. Additional notes on the fossil fishes of the Upper Old Red Sandstone of the Moray Firth Area. Proceedings of the Royal Physical Society of Edinburgh 13:376-385

Traquair, R. H. 1899. Report on fossil fishes collected by the Geological Survey of Scotland in the Silurian rocks of the South of Scotland. Transactions of the Royal Society of Edinburgh 39:827-864.

Traquair, R. H.1900. Notes on Drepanaspis gemündenensis, Schlüter. The Geological Magazine 4(7):153-159.

Vaškaninová, V., and Kraft, P. 2016. A unique occurrence of a psammosteid heterostracan on the peri-Gondwanan shelf in the Lower/Middle Devonian boundary marine deposits. Fossil Imprint 72 (3-4):155-160.

Westoll, T. S. 1967. Radotina and other tesserate fishes. Zoological Journal of the Linnean Society 47:83-98.

White, E. I. 1935. The Ostracoderm Pteraspis Kner and the relationships of the agnathous vertebrates. Philosophical Transactions of the Royal Society B 225:381-457.

Woodward, A.S.1891. Catalogue of the fossil fishes in the British Museum (Natural History). Pt. 2. London: Printed by order of the Trustees.

Woodward, A. S. 1910. A guide to the fossil reptiles, amphibians, and fishes in the Departement of Geology and Palaeontology in the British Museum (Natural History). 9-th edition. London, British Museum. 
Supplementary materials are available on-line at https://biocomm.spbu.ru. https://doi.org/10.21638/11701/spbu03.2017.408

\section{Appendix 1. List of characters.}

Ordered $=$ Ordered character in the matrix.

1. Number of main plates on the dorsal side of cephalothorax (The paired plates are only considered for one side): (0) one to three, (1) four-five, (2) more than five. The paired plates are only considered for one side. After ch.31 of Pernègre \& Elliott (2008). Also ch.28 of Pernègre (2002). Ordered.

2. Position of the mouth: (0) ventral position, (1) dorsal position. Modified from ch.1 of Pernègre (2002). Also ch.38 of Randle \& Sansom (2016). Note: Juvenile Drepanaspis gemuendenensis probably has ventral or terminal position of the mouth.

3. Rostral plate / rostral part of cephalothorax, ventral (recurrent) lamella with pre-oral surface: $(0)$ absent, (1) extremely redused - maxillar brim after Kiaer (1930), Wills (1935), (2) short lamella (less than the half of the dorsal length of rostral plate), (3) long lamella (more than the half of the dorsal length of rostral plate). After ch.55 of Pernègre \& Elliott (2008) and ch.9 of Randle \& Sansom (2016). Also ch.18, 19 (pars), 23 (pars) of Blieck \& Elliott (1984) and ch.1 of Pernègre \& Goujet (2007).

4. Rostral area/plate, anterior margin: (0) convex, rounded anteriorly, (1) convex, rounded anteriorly to a point, (2) convex, triangular, (3) aligned, (4) concave anteriorly. Modified from ch.12 of Randle \& Sansom (2016). Also ch.35 of Pernègre \& Goujet (2007) and ch.30 of Pernègre \& Elliott (2008).

5. Rostral plate, lateral/posterolateral margins (rostro-orbital contact): (0) concave (for orbital plate or tesserae), (1) straight or convex. After ch.24 of Pernègre (2002). Also ch.11 of Pernègre \& Goujet (2007), ch.19 of Pernègre \& Elliott (2008) and ch.13 of Randle \& Sansom (2016). Note: Rostral plate of juvenile Pycnolepis splendens (GIT 116-27) and Psammolepis paradoxa (G 55-1109) hasn't included in analysis.

6. Rostro-orbital contact: (0) present, (1) absent due tesserae. Modified from ch.19 of Pernègre \& Elliott (2008). After ch.24 of Pernègre (2002), ch. 11 of Pernègre \& Goujet (2007).

7. Rostral plate, posterior margin: (0) convex, (1) straight or slightly concave.

8. Rostro-pineal contact: (0) absent, (1) notch for the pineal plate in the rostral plate, (2) planar, (3) absent due tesserae. After ch.28 from Pernègre \& Elliott (2008). Also ch.14 of Pernègre \& Goujet (2007), ch.15 Randle \& Sansom (2016). Note: Psammosteids Schizosteus striatus, Pycnolepis splendens don't have the rostro-pineal contact, because on their posterior margin of rostral plates there are tesserae ('Praepineal field of tesserae'). Ordered.

9. Rostral area/plate, proportions: (0) wider than long, (1) as long as wide, (2) longer than wide. Modified ch.29 of Pernègre \& Elliott (2008). Also ch.5 (pars), 6 (pars), 16, 17 (pars), 19 (pars) from Blieck \& Elliott (1984), ch.15 of Pernègre \& Goujet (2007). Notes: Drepanaspis has different proportions of rostral plate (degrees of compression in Hunsrück Lagerstätte). Specimen GIT 116-170 is the rostral plate of Vladimirolepis proia comb. nov.

10. Praerostral plates: (0) absent, (1) present. Note: For the juvenile Drepanaspis presence of praerostral plates is indicated provisional.

11. Oral plates, posterior contact: $(0)$ with the ventral plate, (1) with lateral postoral (orogonal) plates, (2) with the tesserae. Modified ch.54 of Pernègre \& Elliott (2008). Also ch.1 (pars), ch. 6 (pars), of Blieck \& Elliott (1984), Ch.23 of Pernègre (2002).

12. Orogonal plates (lateral postoral plates): (0) many pairs, (1) 1 pair. After ch.53 of Pernègre \& Elliott (2008). Also ch.8 of Pernègre (2002), ch.39 of Randle \& Sansom (2016). Note: As the orogonal plates of Drepanaspis coded paired median tesserae, complex plates and maybe lateral and medial marginal plates.

13. Pineal plate or macula, their position: (0) pineal macula/plate included in dorsal plate, (1) pineal plate inserted in the dorsal plate. After ch.1 of Randle \& Sansom (2016). Ch.22 of Pernègre \& Elliott (2008).

14. Pineal plate, general morphology: (0) triangular, (1) flat topped ovate /croissant, (2) general quadratangular, (3) rhomboid/polygonal, (4) rhomboid, crown and neck also covered by tubercles. Modified ch.4 of Randle \& Sansom (2016).

15. Pineal plate, anterior margin: (0) convex or stright, (1) concave. After ch.41 of Pernègre \& Goujet (2007). Ch.25 of Pernègre \& Elliott (2008), partly ch.5 of Randle \& Sansom (2016).

16. Orbito-pineal contact: (0) absent, (1) narrow contact (point of contact), (2) broad of contact (orbito-pineal belt). Modified ch.6, 7 of Randle \& Sansom (2016). Also ch.7, 8, 9, 12, 13, 14, 15 of Blieck \& Elliott (1984), ch.25 of Pernègre, 2002, ch.12 of Pernègre \& Goujet (2007), ch.26 of Pernègre \& Elliott (2008). Ordered.

17. Pineal plate position: (0) plate well inserted in dorsal plate (over more than half of its length), (1) plate slightly inserted in the dorsal plate (less than half its length), (2) pineal plate contacts with tesserae. Modified from ch.22 of Pernègre \& Elliott (2008). Also ch.22 of Pernègre (2002), ch.10 of Pernègre \& Goujet (2007). Note: Drepanaspis have well inserted pineal plate in dorsal plate's notch (like in Protopteraspis), unlike as in Doryaspis and other coded Pteraspidiformes.

18. Pineal opening (macula), covering: (0) covered by discrete primordial tubercle, (1) primordium of the pineal plate with a dentine unit, (2) covered by many tubercles on the pineal plate, (3) uncovered (open primordium). Modified of ch.24 from Pernègre \& Elliott (2008). Ch.4 of Donoghue et al. (2000), ch.39 of Pernègre \& Goujet (2007) and ch.2 of Randle \& Sansom (2016).

19. Pineal canal (pc), location: (0) loops around pineal macula/plate, (1) loops through pineal macula/plate. After ch.55, 56 of Randle \& Sansom (2016). Also ch.3 (pars), 
ch. 4, ch. 5(pars) of Blieck \& Elliott (1984), ch.5 of llyes \& Elliott (1994), ch.13 of Pernègre (2002) and ch.51 of Pernègre \& Elliott (2008).

20. Pineal / postpineal canal, pattern: (0) $V$ and $U$ shaped pc (convex to rear), (1) Pc slightly arched, (2) radial pattern. Modified ch.52 of Pernègre \& Elliott (2008). Also ch.11 of Blieck \& Elliott (1984), ch.40 of Pernègre \& Goujet (2007).

21. Orbital area: (0) orbit surrounded by numerous plates (sub-orbitale+dorsale), (1) orbito-cornual plate, (2) orbital plate, (3) orbital and postorbital plate. Modified ch.14, 15 of Pernègre \& Elliott (2008). Ch.2 (pars) and 3 (pars) of Blieck \& Elliott (1984), ch. 12 of Pernègre (2002), ch.16 of Randle \& Sansom (2016). Ordered. Note: Postorbital plates are the result of decay of branchial plates of Pteraspidiformes (Obruchev, 1943).

22. Orbital plates, anterior process: (0) pointed, (1) truncated/convex anterior margin. Modified from ch.18 of Pernègre \& Elliott (2008). Also ch.37 of Pernègre \& Goujet (2007).

23. Orbital plates, median process: (1) short, (2) medium, (3) long. Modified from ch. 17 of Pernègre \& Goujet (2007), ch.16 of Pernègre \& Elliott (2008). Note: The orbital plates of Drepanaspis have the short medial process (Gross 1963, fig. 4M).

24. Orbital/postorbital plates, posterior process length: (0) short, (1) medium-sized, (2) long process, (3) absent posterior process (in Tartuosteus, Psammolepis). Modified from ch.20 of Pernègre \& Elliott (2008). Also ch.8 of Ilyes \& Elliott (1994), ch.26 of Pernègre \& Goujet (2007). Notes: Gigantaspis minima, juvenile Drepanaspis gemuendenensis and Psammosteus bergi (GIT 497-4) have long posterior process of orbital/postorbital plates.

25. Postorbital canal (poc) of lateral-line system: (0) absent, (1) present (one canal), (2) present (radial canals). Modified from ch.16 of Pernègre (2002).

26. Orbital plates, rostral folds (rostral suborbital process) on them: (0) absent, (1) present. After ch.27 of Pernègre \& Elliott (2008). Also ch.7 by llyes \& Elliott (1994), ch.13 of Pernègre \& Goujet (2007).

27. Median plates surrounded by fields of tesserae: $(0)$ absent, (1) present. After ch.28 from Randle \& Sansom (2016). Also ch.1, ch.2 (pars) from Blieck \& Elliott (1984). Notes: Specimen of juvenile Drepanaspis gemuendenensis has fields of tesserae on the dorsal side. They are not covered by macromeric plates of cephalothorax, but don't have a real tesserae (Gross 1963). The young individuals of Drepanaspis gemuendenensis probably have odontodes (single elements, early stage of development of tesserae) which don't fuse in tesserae. The single specimen of juvenile $D$. gemuendenensis has lost during the WWII, as mentioned by Gross (1963). Representatives of most psammosteids have fields of tesserae on the basis of presence isolated tesserae and/or rooted tesserae on the median plates.

28. Accessory plates (postbranchial plates/sub-branchial scales): (0) absent, (1) present. After Ch.6 of llyes \& Elliott (1994). Also ch.26 of Blieck (1984), Ch.9 and ch.27 of Pernègre (2002), ch.5 of Pernègre \& Elliott (2008), ch.40 of Randle \& Sansom (2016).

29. Dorsal shield/plate, width/length ratio: (0) very elongated (width/length ratio less than 0.7$),(1)$ elongated or broad (width/length more than 0.7$)$, (2) isometric or very broad (width/length $\geq 1$ ). After ch.32 of Pernègre \& Elliott (2008). Also ch.16 of Pernègre \& Goujet (2007).

30. Dorsal shield/plate, general shape of adult plate: $(0)$ polygonal without reduced posterior margin (i.e. plate/ shield has posterolateral lobes which contacts with lat- eral plates, (1) rhomboid with anterior and posterior notches, (2) heart-shaped, (3) oval/pear-shaped with narrowing front part, (4) oval with anterolateral lobes. Ordered.

31. Dorsal plate, general shape of primordium (for psammosteids): (0) rhomboid with anterior and posterior notches, (1) heart-shaped, (2) elongated with a narrowing in front. Ordered.

32. Dorsal shield/plate, anterior margin curvature: (0) concave, (1) straight, (2) convex, (3) convex to a point. After ch.38 of Pernègre \& Elliott (2008). Also ch.22 of Pernègre (2002) and ch.10, 45 of Pernègre \& Goujet (2007).

33. Dorsal shield/plate, lateral margins curvature: (0) convex, (1) concavo-convex (pear shape), (2) angular, may also form anterolateral and posterolateral margins (rhomboid /heart-shaped dorsal plate), (3) straight, (4) convexo-concave, (5) convexo-concave with posterolateral process (fam. Obrucheviidae). Modified from ch.24 of Pernègre \& Goujet (2007), ch.34 of Pernègre \& Elliott (2008).

34. Dorsal shield/plate, branchial sinus: (0) absent, (1) present. After ch.31 of Randle \& Sansom (2016). Note: Branchial sinus (Kiaer, 1932) or flexure (Voichyshyn, 2011) is located on the lateral margins of dorsal shield/ plate and serves to position the branchial openings or cornual plates. D. Obruchev noted, that the some dorsal plates of Obruchevia have the branchial sinus (Obruchev, 1941, p. 18).

35. Dorsal shield/plate, posterior margin curvature: (0) concave (1) straight, (2) convex (rounded), (3) convex (angular). Modified ch.27 of Pernègre \& Goujet (2007). Also ch.35 of Pernègre \& Elliott (2008), ch.29 of Randle \& Sansom (2016). Notes: Margin curvature without shape of median posterior process. The shape of the posterior margin of plates can be restored by growth lines. Some psammosteids with rhomboid and heart-shaped dorsal plate have very thin posterior margin, but have the median posterior process.

36. Dorsal shield/plate, contact between posterior and lateral margins: (0) obtuse angle, (1) arc-shaped contact. Modified ch.37 of Pernègre \& Elliott (2008). Also ch.44 of Pernègre \& Goujet (2007).

37. Dorsal shield/plate, median posterior process on the posterior margin (mid-posterior process, posterior medial peak): (0) absent, (1) present. After ch. 29, 32 of Randle \& Sansom (2016).

38. Dorsal plate, posterior notch of the dorsal plate (for the independent dorsal spine or ridge-scale): (0) present, open, (1) present, enclosed, (2) absent. Ordered. Modified from ch.3 of Ilyes \& Elliott (1994), ch.2 of Pernègre (2002), ch. 33, 35 of Randle \& Sansom (2016). Note: Drepanaspis gemuendenensis has posterior notch with fold.

39. Dorsal spine: (0) present, fused to dorsal plate, (1) present, independent dorsal spine, (2) absent. Modified from ch.2 of Pernègre (2002). Also ch.1 (pars) from Blieck \& Elliott (1984), ch.10 of Pernègre \& Elliott (2008), ch. 34 of Randle \& Sansom (2016). Note: Drepanaspis gemuendenensis hasn't the dorsal spine.

40. Dorsal shield/plate, transverse commissures (tc or radiating commissures): (0) 3 pairs, (1) 2 pairs, (2) more than 3 pairs, (3) absent. Modified from ch. 3 of Pernègre (2002). Note: The exact quantity of transverse commissures for Perscheia pulla is not known.

41. Dorsal shield/plate, transverse commissures pattern, anterior (first) pair: (0) stright or convex anteriorly, (1) concave anteriorly. After ch.40 of Pernègre \& Elliott. Also ch.59 of Randle \& Sansom (2016). 
42. Dorsal shield/plate, transverse commissures pattern, middle (second) pair: (0) straight or convex anteriorly, (1) concave anteriorly. After ch.41 of Pernègre \& Elliott (2008). Also ch.30 of Pernègre \& Goujet (2007), ch.60 of Randle \& Sansom (2016).

43. Dorsal shield/plate, transverse commissures pattern, posterior (third) pair: (0) straight, (1) concave anteriorly, (2) convex anteriorly. After ch.42 of Pernègre \& Elliott (2008). Also ch.31 of Pernègre \& Goujet (2007) and ch.61 of Randle \& Sansom (2016). Note: In the analisys have used data on juvenile Placosteus undulatus (GIT 116-231) in which represented the lateral line system.

44. Dorsal shield/plate, median transverse commissures (mtc): (0) absent, (1) presence on the anterior part of the plate (near with pair tc1-tc2), (2) presence on the posterior part of the plate (near with pair tc2-tc3). After ch.43 of Pernègre \& Elliott (2008). Also ch.62 of Randle \& Sansom (2016).

45. Dorsal plate, median transverse commissures (mtc), quantity: (0) two, (1) one. Note: The exact quantity of median transverse commissures for Perscheia pulla is not known.

46. Dorsal shield/plate, median dorsal canals (mdc), anterior part: (0) diverge, (1) converge or parallel, (2) mdc are absent. After ch.44 of Pernègre \& Elliott (2008). Also ch.22 of Blieck \& Elliott (1984), ch.15 of Pernègre (2002), ch.4 of Pernègre \& Goujet (2007), ch.53 of Randle \& Sansom (2016).

47. Dorsal shield/plate, anterior mdc begins on the dorsal shield/disc without connection to any other canals: (0) absent, (1) present. After ch.54 of Randle \& Sansom (2016). Also ch.45 of Pernègre \& Elliott (2008).

48. Dorsal plate, mdc anterior prolongation: $(0) \mathrm{mdc}$ not prolonged anteriorly, (1) between orbital and pineal areas/plates, (2) pineal plate, (3) orbital plate, (4) meets pineal canal on the dorsal plate. After ch.45 of Pernègre \& Elliott (2008) and ch.52 of Randle \& Sansom (2016). Also ch19 of Pernègre \& Goujet (2007) and ch.45 of Pernègre \& Elliott (2008).

49. Dorsal shield/plate, lateral dorsal canal (Idc): (0) absent, (1) present on the shield/plate, (2) present in the fields of tesserae. Note: The lateral dorsal canal of Perscheia pulla and of some Psammosteus is located along the lateral margins of the plate. Perhaps Perscheia pulla had narrow fields of tesserae, or they were not at all.

50. Dorsal shield/plate, contact between the anterior transverse commissures (tc) and the lateral dorsal canal (Idc): (0) the anterior tc contacts the Idc on its anterior third, (1) the anterior tc contacts the Idc on its medial third. (2) the anterior tc contacts the Idc somethere in the fields of tesserae. Modified ch.46 of Pernègre \& Elliott (2008). Ch.22 of Pernègre \& Goujet (2007), ch.65 of Randle \& Sansom (2016). Note: Psammosteus megalopteryx and Psammosteus bergi perhaps have the contact in the bases of the rooted tesserae.

51. Dorsal shield/plate, position of the lateral dorsal canal (Idc): (0) Idc very far from the lateral margins of the dorsal plate, (1) Idc moderately far from the lateral margins of the dorsal plate, (2) ldc close to the lateral margins of the dorsal plate. After ch.47 of Pernègre \& Elliott (2008). Ch.21 of Blieck \& Elliott (1984), ch.25 of Pernègre \& Goujet (2007).

52. Posterior prolongation of the supraorbital canals (soc): (0) soc between the orbital and pineal areas or in the pineal plate, (1) soc on the orbital plate. After ch.48 of Pernègre \& Elliott (2008). Ch.20 of Pernègre \& Goujet (2007) and ch.50 of Randle \& Sansom (2016).
53. Position of posterior part of soc: (0) medial, (1) lateral (also in the fields of tesserae). Modified ch.51 of Randle \& Sansom (2016).

54. Dorsal shield/plate, type of ornamentation \& grow: (0) lateral addition of dentine ridges (longitudinal ridges), (1) concentric ridges from a primordium, (2) concentric rows of tubercles from a primordium, (3) absent (tesserae). Modified from ch.6 of Pernègre \& Elliott (2008). Also ch.17 (pars) of Blieck \& Elliott (1984), ch. 10 of Pernègre (2002), ch.6 of Pernègre \& Elliott (2008), ch.43 of Randle \& Sansom (2016). Ordered.

55. Dorsal shield/plate, growth center (ornamentation's primordium), their position: (0) lack of primordium, (1) anterior half of the plate, (2) near half of the plate, (3) posterior half of the plate. Modified from ch.11 of Pernègre (2002) and ch.44 of Randle \& Sansom (2016). Also ch.7 of Pernègre \& Goujet (2007), ch.8 of Pernègre \& Elliott (2008).

56. Dorsal shield/plate, density of ornamentation on the dorsal disc: (0) ridge (or tubercle) density equal or superior to 10 per millimetre, (1) density inferior to 10 per millimetre. After ch.7 of Pernègre \& Elliott (2008). Also ch.29 of Pernègre (2002), ch. 6 of Pernègre \& Goujet (2007).

57. Dorsal shield/plate, degree of coverage of the rooted tesserae: (0) absent, (1) rare single tesserae, (2) numerous tesserae (small primordium not covered by tesserae), (3) numerous tesserae (large primordium (independent plate) not covered by tesserae), (4) numerous tesserae (partial covering with the mosaic of own superficial layer (see Obruchev \& Mark-Kurik, 1965, text-fig. 170)), (5) dorsal plate full covered by tesserae. Ordered.

58. Dorsal plate, tesserae on the primordium : (0) absent, (1) present.

59. Dorsal plate, maximal sizes of the rooted tesserae: (0) large (more than $1.6 \mathrm{~cm}),(1)$ medium $(0.8-1.6 \mathrm{~cm})$, (2) small $(0.2-0.8 \mathrm{~cm})$.

60. Dorsal plate, dominated shape of the rooted tesserae and overlapping: (0) scale-like, rhombic, square, with overlapped margins, (1) scale-like, rhombic, square, not overlapped margins, (2) polygonal, not overlapped margins.

61. Dorsal plate, groove type of the rooted tesserae: (0) cyclomorial, concentrical position of primordial tubercle, (1) cyclomorial, eccentric position of primordial tubercle, (2) synchronomorial.

62. Dorsal plate (and other main plates), degree of rooting of the bases of the rooted tesserae: (0) dense rooting, (1) weak rooting with development canals in the aspidin.

63. Dorsal shield/plate, internal organ impressions on the visceral surface: (0) present, (1) absent. After ch.38 of Pernègre \& Goujet (2007), ch.36 of Pernègre \& Elliott (2008), ch.41 of Randle \& Sansom (2016).

64. Ventral plate, form of the primordium (shape of the juvenile plate): (0) posterior notch is present (small Vshaped), (1) posterior notch is present (large V-shaped), (2) posterior notch is present (large U-shaped), (3) oval shape, posterior notch is absent, (4) primordium isn't distinguishable due the tesserae pattern. Ordered.

65. Ventral plate, width/length ratio: (0) elongated (width/length ratio $0.5-0.7$ ), (1) broad (width/length ratio more than 0.7$)$, (2) very elongated (width/length ratio less than 0.5 ).

66. Ventral shield/plate, anterior margin shape: (0) concave or straight in the middle, (0) convex. Notes: Data on Drepanaspis from Gross (1963), Obruchev \& Mark-Kurik (1965), pp. 38, 39. Lateral margins of ventral plates of all representatives have the same shape. 
67. Ventral shield/plate, posterior margin shape and shape of posterior notch: (0) convex angular, (1) convex (2) straight or slightly concave, (3) V-shaped / thin posterior notch, (4) U-shaped / broad posterior notch, (5) secondary convex (overgrown of V-shaped posterior notch/ O-shaped growth center), (6) secondary convex, with posterior middle process (Psammosteus). Note: Character state provisionaly indicated for the juvenile Drepanaspis.

68. Ventral plate, ratio of length of posterior notch (L1) and ventral plate (L2): (0) short posterior notch (L1) $\mathrm{L} 2=0.1-0.25)$, (1) middle sized ( $\mathrm{L} 1 / \mathrm{L} 2=0.3-0.5)$, (2) long (L1/L2 more than 0.5), (3) extreme long (L1/L2 = 0.8).

69. Ventral plate, protruding edges of the posterior notch: (0) absent, (1) present (visceral side bears a thin line of oramented surface, protruding edges usually covering by pleuromin (Pycnosteus, Ganosteus).

70. Ventral shield/plate, position of primordium (growth center): (0) posteriorly, (1) middle/near the middle, (2) anteriorly.

71. Ventral shield/plate, covering by rooted tesserae: $(0)$ absent, (1) few tesserae in posterior notch and on the posterior parts of plate (Schizosteus, Tartuosteus, Ganosteus), (2) posterior pattern of tesserae, (3) lateral and posterior pattern of tesserae, (4) full covering by tesserae. Ordered.

72. Ventral plate, shape of rooted tesserae and overlapping: (0) mostly scale-like (growing up), rhombic, square, overlapped margins ('Psammolepis'-shape), (1) scale-like, rhombic, square, not overlapped margins, (2) mostly polygonal ('Psammosteus'-shape).

73. Ventral plate, groove type of the rooted tesserae: $(0)$ cyclomorial, concentrical position of primordial tubercle, (1) cyclomorial, eccentrical position of primordial tubercle, (2) synchronomorial.

74. Ventral plate, sizes of the rooted tesserae: (0) big (more than $1.6 \mathrm{~cm})(1)$ medium $(0.8-1.6 \mathrm{~cm})(2)$ small sized $(0.2-0.8 \mathrm{~cm})$.

75. Ventral shield/plate, presence of the postoral canal (polc): (0) absent, (1) present. After ch.3 of Pernègre \& Goujet (2007). Ch.14 of Pernègre (2002), ch.57 of Pernègre \& Elliott (2008). Note: Drepanaspis gemuendenensis has the postoral canal. Presence of postoral canal is an indicator of a floating lifestyle, rather than burial lifestyle.

76. Ventral shield/plate, presence of the paired lateral ventral canal (Ivc): (0) Ivc (only) present, (1) Ivc with transverse commissures, (2) absent, only transverse commissures. Note: The most psammosteids have Ivc in the ventrolateral fields of tesserae.

77. Branchial plates reaches the proximal margins of the cephalothorax: (0) absent, (1) present.

78. Branchial plates, lateral/anterolateral ledge: (0) absent, (1) present. Note: Anglaspis and psammosteids have the lateral/anterolateral ledge on the branchial plates.

79. Branchial plates, dorsal lamella: (0) lack of dorsal lamella, (1) width of ventral and dorsal lamellae equal, (2) unequal width of lamellae, (3) lamellae are partly fused, free anterolateral ledge and distal tip, (4) lamellae are fully fused. Modified ch.4 of Pernègre \& Elliott (2008), ch.20 of Blieck \& Elliott (1984). Ordered. Note. The anterolateral ledge also call as the free laterally projecting margin (Halstead Tarlo, 1965, p. 40).

80. Branchial plates, branchio-dorsal contact: (0) long, more than half disc length, (1) short, less than the half disc length, (2) lack of contact. After ch.33 of Pernègre \& Elliott (2008). Also ch.23 of Blieck \& Elliott (1984), ch.23 of Pernègre \& Goujet (2007). Note: Psammosteids probably have the contact of medial part of branchial plates with visceral side of the dorsal plate, but we do not see this contact under the tesserae. For either psammosteid the character state established on the basis of eurybasal/ stenobasal form of it branchial plates.

81. Branchial plates, length-width ratio (l:w): (0) narrow eurybasal (more than $1.5-2$ ), (1) isometric eurybasal (more than 0.9 to 1.5$)$, (2) wide eurybasal (more than 0.6), (3) stenobasal (less than 0.6), (4) extremely short stenobasal (less than 0.3 ). Note: Narrow eurybasal branchial plates perform mainly the function of the bearing surface (underwater gliding), more wide plates also adapted for the supports on the ground. Modified ch.4 (pars), ch.17 (pars), ch.23 (pars) of Blieck \& Elliott (1984). Ordered.

82. Branchial plates, shape of lateral/anterolateral margin: (0) slightly convex, (1) arcuate convex (arc-shape for Protaspis, Psammolepis), (2) generally concave, (3) linear. Modified ch.23 of Blieck \& Elliott (1984).

83. Branchial plates, shape of medial margin: (0) straight or concave (also arc-shape for Protaspis), (1) anterior part is concave and posterior part is slight convex (eurybasal), (2) with anterior concave and posterior expressed convex (eurybasal), (3) anterior part is short (stright/convex) and posterior part is expressed convex (eurybasal/stenobasal), (4) expressed convex (stenobasal). Ordered.

84. Branchial plates, shape of posterior margin: (0) convex posteriorly, (1) straight or concave posteriorly. Note: The juvenile branchial plate of Pycnosteus palaeformis, described by Glinskiy (2014) not included in the analysis.

85. Branchial plates, distal tip: (0) back oriented (divergent), (1) back oriented (convergent), (2) forward oriented, (3) truncated (for Obruchevia).

86. Branchial plates, ratio of the ornamented/unornamented surface $\left(w_{1}: w_{2}\right)$ on the dorsal side of plates: (0) ornamented surface is narrow (from 0,2 up to 0,5), (1) equally (from 0,5 up to 1 ), (2) ornamented surface is wide (more less 1). Ordered.

87. Branchial plates, ratio of the ornamented/unornamented surface $\left(w_{1}: w_{2}\right)$ on the ventral side of plates: (0) unornamented surface is narrow, (1) expanded unornamented surface, (2) extremely expanded unornamented surface (for representatives of Psammosteus). Ordered.

88. Branchial openings, position: $(0)$ at the second half of branchial plate, (1) at the distal tip of branchial plate, (2) at the posterior margin of branchial plate. Modified ch. 1 of Pernègre \& Elliott (2008). Ch.1 of Ilyes \& Elliott (1994), ch. 20 of Pernègre (2002), ch.5 of Pernègre \& Goujet (2007), and ch.20 of Randle \& Sansom (2016). Ordered.

89. Branchial openings, delimitation: (0) superior margin of branchial plate, (1) posterior margin of branchial plate, (2) lateral margin of the dorsal plate. Modified ch.2 of Pernègre \& Elliott (2008). Ch.1 of Ilyes \& Elliott (1994), ch.36 of Pernègre \& Goujet (2007) and ch.19 from Randle \& Sansom (2016). Ordered.

90. Cornual plates: (0) absent, (1) fused with other plates, (2) cornual plates sensu stricto with cornua, (3) rudimentary and very reduced cornual plates. After ch.12 of Pernègre \& Elliott (2008). Also ch.1 (pars), 24, 25 of Blieck \& Elliott (1984), ch.1 of llyes \& Elliott (1994), ch.4 of Pernègre (2002), ch.9 of Pernègre \& Goujet (2007), ch.21 of Randle \& Sansom (2016). Note: Drepanaspis gemuendenensis has redused (truncated) cornual plates without cornua.

91. Cornual plates, length-width ratio: (0) narrow (l>W), (1) broad (l=W), (2) very broad $(\mathrm{l}<\mathrm{W})$. Modified ch.13 of Pernègre \& Elliott (2008). Also ch. 24 of Blieck \& Elliott (1984), ch.23 of Randle \& Sansom (2016). 
92. Cornual plates, general shape: (0) triangular, (1) rectangular, trapezium-shape. Note: Shape of cornual plates of Drepanaspis gemuendenensis is variable (Obruchev \& Mark-Kurik, 1965, p. 35), juvenile form has triangular cornual plates.

93. Cornual plates, margins: (0) lateral (external) and posterior margins straight/convex, (1) lateral (external) margin concave and posterior margin convex, (2) lateral (external) margin convex and posterior side concave. Modified ch.22 of Randle \& Sansom (2016).

94. Cornual plates, posterior extension: (0) less than posterior margin of dorsal plate, (1) equal to posterior margin of dorsal plate, (2) greater than posterior margin of dorsal plate. After ch.24 of Randle \& Sansom (2016).

95. Cornual plates, ornamentation: (0) scale-like ornamentation, (1) long ridges parallel to the lateral (external) edge, (2) like on the median plates. After ch.25 of Randle \& Sansom (2016).

96. Cornual plates, lateral projection: (0) lateral projection less than brachial plate, (1) lateral projection the same as brachial plates, (2) lateral projection just up to greater than double that of the branchial plates, (3) lateral projection vastly greater than brachial plate, (4) cornual plates placed on dorsal shield. After ch.23 of Randle \& Sansom (2016).

97. Cornual - ventral contact: absent (0), present (1). After ch.21 of Pernègre (2002). Note: Ornamentation doesn't present on the visceral side of cornual plate, which not contacting with ventral plate.

98. Flank scales, morphology: (0) short and broad, (1) rombic shape with short unornamented surface, (2) rombic/ round shape with extended unornamented surface.

99. Flank and ridge scales, groove lines and ornamentation: (0) longitudinal / transversal ridges, (1) V-/arc- ordered ridgelets/tubercles, (2) areal groove zones of ridgelets/tubercles (like in cyclomorial tesserae, primordial tubercle located close to the center of scale). Ordered.

100. Flank scales, rows of lateral squamation: (0) reduced number of rows, about two, (1) more than 2 rows. After ch.17 of Pernègre (2002). Ch.58 of Pernègre \& Elliott (2008). Note: The squamation is unknown in many taxa, but the size of isolated scales allows an approximation of the number of lateral rows of scales.

101. Flank scales, relative width in different rows: $(0)$ different width, (1) same width. After ch. 26 of Pernègre, 2002.

102. Flank scales, relative length: $(0)>$ than ridge scales, (1) equal to ridge scales, (2) < than ridge scales. After ch.18 of Pernègre (2002). Ch.59 of Pernègre \& Elliott (2008).

103. Flank scales, sizes: (0) large (up to $1.6 \mathrm{~mm}$ ), (1) medium (0.8-1.6 mm), small (less than $0.8 \mathrm{~mm}$ ) (Psammosteus).

104. Flank scales, row of subperpendicular dentine ridges on the free margins (like in Drepanaspis, Schizosteus): (0) present, (1) absent. Note: Psammolepis toriensis, Traquairosteus ? ramosus have circular pattern of dentine ridgelets not on the free margins.

105. Caudal fin, type: (0) heterocercal, (1) hypocercal, (2) homocercal.

106. Fields of tesserae, average sizes of discrete tesserae: (0) large $(1.8-3 \mathrm{~cm})(1)$ medium $(1 \mathrm{~mm}$ up to $1.8 \mathrm{~cm})$ (2) small (less than $1 \mathrm{~mm}$ ). Note: In case if the material on the isolated tesserae is not known, were also used data on rooted tesserae.

107. Fields of tesserae, presence of the single elements and complex elements (not in juvenile forms): (0) absent, (1) present.
108. Tesserae, morphology, morpho-histological type of the discrete elements: $(0)$ scale lake with overlapping zones, (1) scale-like without overlapping zones, (2) mostly polygonal, basic type, discrete tesserae with high neck, (3) mostly polygonal, basic type, discrete tesserae with low neck, (4) progressive type. Note: In cases where material of the isolated tesserae is not known, data on rooted tesserae were used. For the additional information see Glinskiy \& Nilov (2017). Ordered.

109. Ornamentation, general pattern on the main plates: (0) uniform (continuous ridges / continuous tubercle bands pattern), (1) undulating ridges (tuberculated ridges only), (2) rows of ridges and tubercles, (3) rows of discrete tubercles (up to 3 tubercles may fuse together in the «ridgelets»), (4) pleromin. Modified ch.42, 47 of Randle \& Sansom (2016). Ch.2 of Ilyes \& Elliott (1994), partly ch.9 of Pernègre \& Elliott (2008). Note: Drepanaspis gemuendenensis has rows of ridges and tubercles, see Gross, 1963, p. 139.

110. Ornamentation, relative position of ridges/tubercles: (0) very dense position (so called 'parquet'), (1) between the tubercles are visible the solitary pores of aspidin, (2) far position of relative tubercles.

111. Ornamentation, the dominant sizes of tubercle bases: $(0)$ very small (less than $0.3 \mathrm{~mm}),(1)$ small $(0.3-$ $0.7 \mathrm{~mm})$, (2) middle $(0.7-1 \mathrm{~mm}),(3)$ large $(1-1.5 \mathrm{~mm})$, (4) very large (more than 1.5).

112. Ornamentation, primordial tubercles surrounds by satellite tubercles (on the main plates excluding tesserae): (0) absent, (1) present.

113. Ornamentation, tops of dentine ridges/tubercles: $(0)$ smooth, (1) crested/sharpened. Adapted from ch.46 of Randle \& Sansom (2016).

114. Ornamentation, margins of dentine ridges/tubercles: (0) smooth (radial ribs do not pass into the marginal serrations/crenulations), (1) radial ribs form the serrations, (2) simple crenulations (tips branch rare), (3) complete crenulations (tips branch often), (4) very complete crenulations (branching tips and branching on the entire length of crenulations). Modified ch.45 of Randle \& Sansom (2016). Also ch.6 of Blieck \& Elliott (1984), ch.21 of Pernègre \& Goujet (2007), partly ch.9 of Pernègre \& Elliott (2008).

115. Ornamentation, orientation of dentine ridges on the branchial plates: (0) subparallel to the anterolateral margin (1) worm-like shapes, (2) subperpendicular to the anterolateral margin, convex distally, (3) subperpendicular to the anterolateral margin, convex proximally.

116. Cell imprints on the surface of tubercles: (0) absent, (1) present, poorly visible or maybe rare, (2) present, expressed and numerous.

117. Pleromin: (0) absent, (1) present, (2) present (full covering). Ordered.

118. Aspidin reticular layer (L1) of the median plates of cephalothorax: (0) absent, (1) present. Histological information from Novitskaya (1965), Novitskaya (2004), Keating et al. (2015).

119. Aspidin mounds /ridges of L1 on the main plates: (0) absent, (1) present.

120. Aspidin layer (L2) of the median plates of cephalothorax: (0) cancellar, (1) compact. Note: Histological information from Novitskaya (1965), Novitskaya (2004), Keating et al. (2015) etc. 